
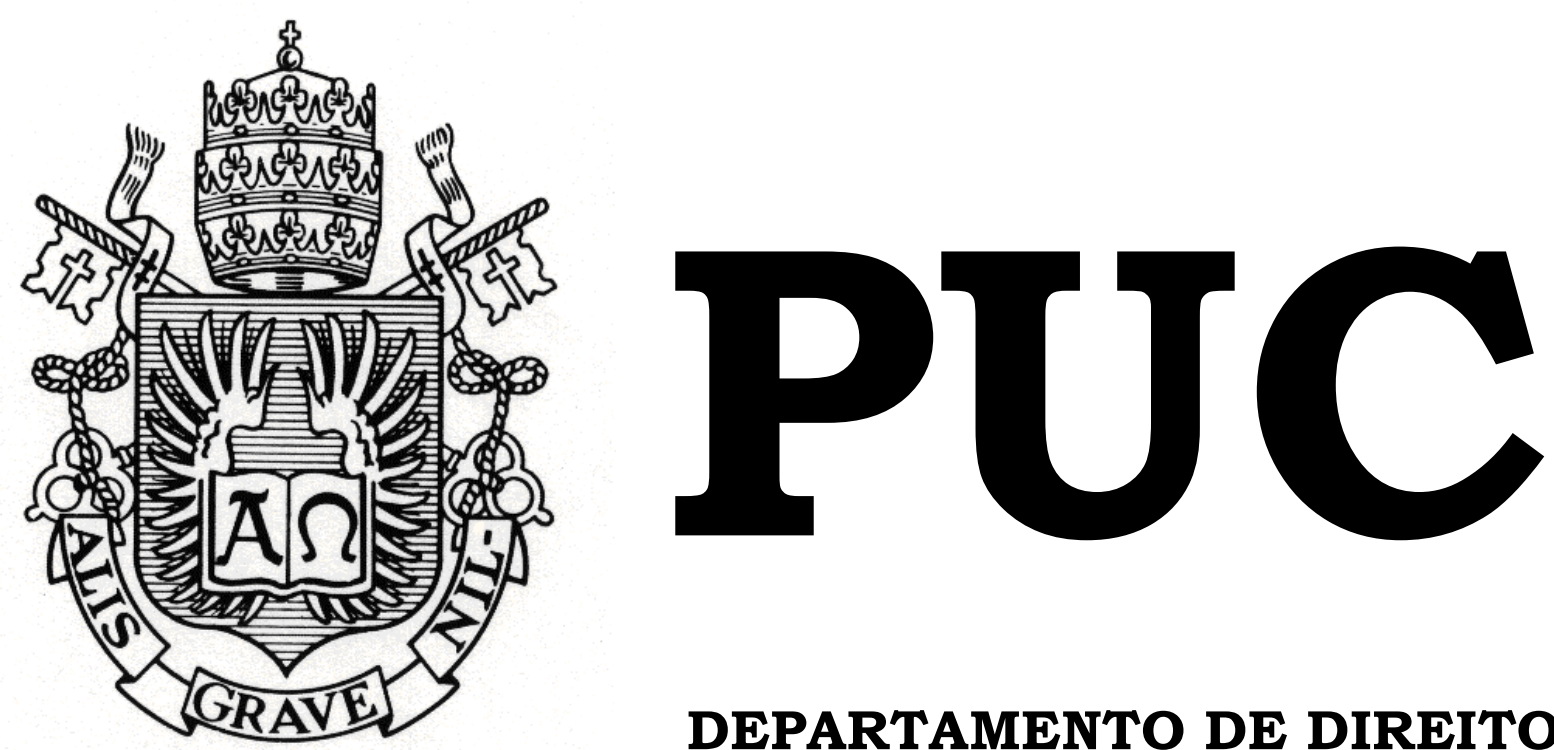

DEPARTAMENTO DE DIREITO

\title{
ASSOCIAÇÃO DE PROTEÇÃO E ASSISTÊNCIA AOS CONDENADOS (APAC): UMA OUTRA PERSPECTIVA NA EXECUÇÃO PENAL
}

por

NATASHA HOHLENWERGER FERREIRA DOS SANTOS

Orientador: ANDRÉ PERECMANIS

2018.2

PONTIFÍCIA UNIVERSIDADE CATÓLICA DO RIO DE JANEIRO

RUA MARQUÊS DE SÃO VICENTE, 225 - CEP 22453-900

RIO DE JANEIRO - BRASIL 


\title{
ASSOCIAÇÃO DE PROTEÇÃO E ASSISTENCIA AOS CONDENADOS (APAC): UMA OUTRA PERSPECTIVA NA EXECUÇÃO PENAL
}

\author{
por \\ NATASHA HOHLENWERGER FERREIRA DOS \\ SANTOS
}

\begin{abstract}
Monografia apresentada ao Departamento de Direito da Pontificia Universidade Católica do Rio de Janeiro (PUC-Rio) como requisito parcial para a obtenção do Título de Bacharel em Direito.
\end{abstract}

Orientador: André Perecmanis 
Dedico essa monografia aos meus pais, Rosangela Hohlenwerger e Sergio Fernando Ferreira dos Santos, por serem o meu exemplo e a força de todas as minhas conquistas.

Dedico também à Rosemary Schettini Hohlenwerger, minha querida madrinha, que através do Grupo Mulheres do Brasil possibilitou meu primeiro contato com a APAC, objeto do presente estudo. 


\section{AGRADECIMENTOS}

Aos meus pais, Rosangela e Sergio, e ao meu irmão, Guilherme, pelo amor incondicional, aposta cega e apoio imensurável,

À minha família e amigos, por serem a minha alegria e refúgio,

Ao meu namorado, Roberto, pelo companheirismo e paciência em todas as horas,

À equipe do escritório Barandier Advogados Associados, na pessoa de Marcio Barandier, por me proporcionarem a vivência com o Direito Penal, com ensinamentos intermináveis e um excelente clima de trabalho, Ao meu orientador, André Perecmanis, por toda a ajuda,

Muito obrigada! 


\section{RESUMO}

SANTOS, Natasha Hohlenwerger Ferreira dos. ASSOCIAÇÃO DE PROTEÇÃO E ASSISTÉNCIA AOS CONDENADOS (APAC): uma nova perspectiva na execução penal. Rio de Janeiro, 2018.87 p. Monografia de final de curso - Departamento de Direito, Pontifícia Universidade Católica do Rio de Janeiro.

O presente trabalho busca analisar o sistema penitenciário brasileiro e a realidade das prisões brasileiras, questionando a dificuldade de ressocialização em determinadas circunstâncias. Além disso, expõe um modelo alternativo de prisão, a chamada Associação de Proteção e Assistência aos Condenados, ressaltando os pontos positivos e suas diferenças frente ao sistema comum.

Palavras chave: Sistema penitenciário brasileiro. Ressocialização. Modelo alternativo prisional. Associação de Proteção e Assistência aos Condenados. APAC. 
INTRODUÇÃO .................................................Erro! Indicador não definido.

\section{Capítulo I - O sistema penitenciário brasileiro e o mito da}

ressocialização como objetivo pretendido. ...................................................... 11

1.1 Os mecanismos de um sistema penal discriminatório ................ 11

1.2 O tripé dos objetivos da pena e sua ruína inevitável........................ 20

Capítulo II - Uma análise da Lei de Execuções Penais (LEP)

frente à realidade do cárcere ................................................................................. 24

2.1 A incongruência dos objetivos da pena e a sua reprodução

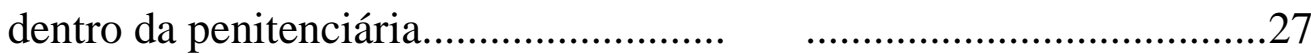

2.2 A superlotação dos presídios sob o viés da assistência material.......31

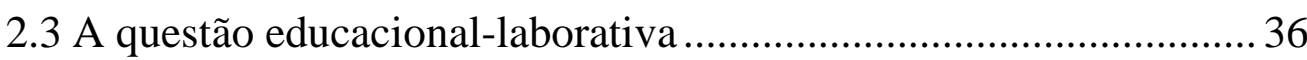

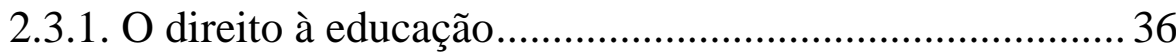

2.3.2 O direito ao trabalho …………………………………………......... 39

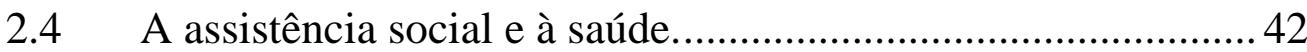

2.5 Lei $x$ Realidade, como atuar?....................................................47

Capítulo III - A assistência ao egresso e a reincidência analisadas frente ao fracasso da Pena Privativa de Liberdade e o papael das penas e medidas alternativas no cenário atual ............................................................ 49

3.1 A assistência ao egresso e a reincidência criminal brasileira ... 49

3.2 As penas e medidas alternativas como desafogamento do sistema carcerário e tentativa de interação com a sociedade ...................53

3.3 O direito penal mínimo e a prisão como um mal (ainda) necessário .56

Capítulo IV - Outros rumos na execução penal: o método APAC....... 60

4.1 A natureza jurídica da APAC em comparação com as Parceiras Público Privadas (PPP`s)......................................................................60

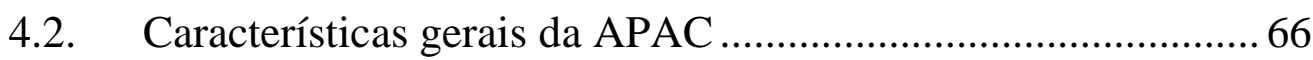

4.3 O histórico do método e suas 12 diretrizes.................................. 68 


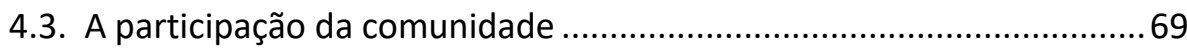

4.3.2 O recuperando ajudando recuperando ...............................................69

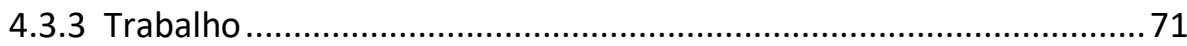

4.3.4 A religião e a importância de se fazer a experiência de Deus ............. 72

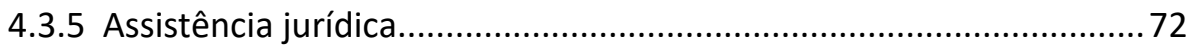

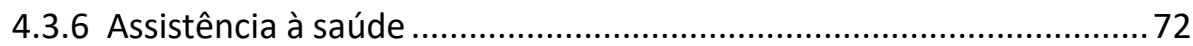

4.3.7 Valorização Humana, base do método APAC ...................................... 73

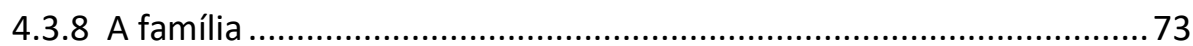

4.3.9 O voluntário e o curso para sua formação .......................................... 74

4.3.10 Centro de Reintegração social (CRS) .............................................. 75

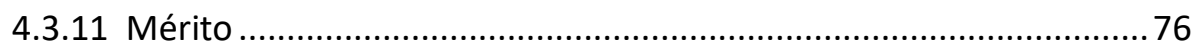

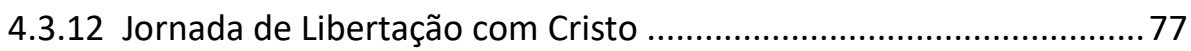

4.4 A rotina na APAC ............................................................. 77

4.5 O método em números.......................................................... 79

4.6 Ponto que merece questionamento....................................... 84

4.6.1 A religiosidade como fator obrigatório para o sucesso do método.....84

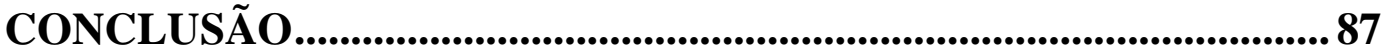

BIBLIOGRAFIA..............................................................................90 


\section{LISTA DE ABREVIAÇÕES}

APAC - Associação de Proteção e Assistência aos Condenados

ART. - Artigo

CNJ - Conselho Nacional de Justiça

CNPCP - Conselho Nacional de Política Criminal e Penitenciária

CP - Código Penal

CRS - Conselho Reintegração Social

DEPEN - Departamento Penitenciário Nacional

INFOPEN - Levantamento Nacional de Informações Penitenciárias

IPEA - Instituto de Pesquisa Econômica Aplicada

LEP - Lei de Execuções Penais

PFI - Prision Fellowship Internacional

PPL - Pena Privativa de Liberdade

PPP - Parceria Público Privada

PRD - Pena Restritiva de Direito 


\section{INTRODUÇÃO}

O sistema retributivo-punitivo com base no modelo de prisão-sanção sempre esteve atrelado à necessidade de contenção de uma determinada parcela social para manter o status quo da classe hierarquicamente dominante no molde capitalista. Por ser um modelo fortemente discriminatório, recolhe às penitenciárias indivíduos que portam características determinadas e que para a sociedade não interessa a sua ressocialização.

Em um primeiro momento, será analisada como essa discriminação está atrelada a diversos mecanismos jurídicos, colocando na mão dos legisladores e do juiz o poder de decidir quem criminalizar. Serão explorados os objetivos oficiais da pena e a impossibilidade de coexistência entre eles, o que acarreta a preferência pelos os que atendem à uma demanda socialmidiática de segurança, deixando de lado o vetor de recuperação, que visa o retorno do preso à sociedade.

Uma vez elencados no plano teórico os objetivos da pena e os problemas estruturais de sua aplicação, adentrar-se-á o sistema penitenciário na prática, fazendo-se uma comparação entre o que a Lei de Execuções Penais (LEP) dita como direitos do preso e o que é aplicado na prática. Com isso, será ressaltado como a impossibilidade de ressocialização do plano teórico é confirmada na realidade, com a demonstração numérica de como a falta de garantias está vinculada diretamente ao interesse em privilegiar os aspectos preventivo-retributivo da pena.

Logo após a demonstração da falência do instituto da prisão como forma de ressocialização do preso, será feita uma análise de como, atualmente, a sociedade punitivista dificulta se pensar em uma abolição do direito penal como solução. Com receio dos tempos que viriam caso a sociedade fosse o juiz dos "criminosos", o direito penal sob a forma da prisão continua sendo visto, apesar de todas as omissões, como um garantidor de

direitos. Deve, porém, ser sempre a ultima ratio, devendo sempre se 
possibilitar a aplicação de medidas alternativas à pena privativa de liberdade, que também serão abarcadas no presente estudo.

Assim, optando-se por seguir a ideia de um Direito Penal Mínimo, o trabalho expõe um modelo alternativo de prisão, a Associação de Proteção e Assistência aos Condenados (APAC), que sob a forma de associação civil tem como objetivo assegurar aos seus recuperandos todos os direitos previstos na LEP, proporcionando diferenciada de rotina e de tratamento, visando, sobretudo, a sua ressocialização. 


\section{Capítulo I - 0 sistema penitenciário brasileiro e o mito da ressocialização como objetivo pretendido}

\subsection{Os mecanismos de um sistema penal discriminatório}

Neste título pretende-se demonstrar que o modelo brasileiro contemporâneo de justiça penal é um modelo discriminatório, e que para isso contribuem diversos fatores. Desde o surgimento das penas como método de punição até os dias de hoje, passando pelos castigos corporais e culminando na pena privativa de liberdade, o direito de punir sempre esteve nas mãos de poucos membros da sociedade, pertencentes a altos cargos. Isso gerou, na maioria das vezes, uma necessidade de defender essa hierarquia de qualquer tipo de usurpação através de leis que preveem os delitos.

Para isso se estruturaram diversos mecanismos jurídicos que deram à tal necessidade de contenção, um ar institucional. A fim de analisar tais mecanismos e o porquê da sua classificação como discriminatórios, se faz necessário retornar ao momento do surgimento do direito de punir.

Cesare Beccaria explica esse fenômeno em seu livro "Dos delitos e das penas". Nele, o autor faz uma reflexão acerca da necessidade dos homens, a partir de certo momento da história, se reunirem e abrirem mão de parte de sua liberdade para diminuir a insegurança, as guerras e as inimizades. $\mathrm{O}$ depositário dessas "liberdades" que foram abdicadas por cada indivíduo foi chamado de soberano, e seria ele o responsável por administrar a lei e o povo.

Sobre essa dinâmica social, Hannah Arendt, em seu livro "Origens do Totalitarismo", reflete que "não nascemos iguais; tornamo-nos iguais como membros de um grupo por força da nossa decisão de nos garantirmos direitos reciprocamente iguais." 1

\footnotetext{
${ }^{1}$ ARENDT, Hannah. Origens do Totalitarismo: antissemitismo, imperialismo e totalitarismo. Companhia das Letras, $3^{\mathrm{a}}$ ed., 2013, p. 335.
} 
Depois de fixadas as condições desse contrato social, percebeu-se que apenas dar o poder na mão de um soberano não era suficiente. Precisava-se criar um mecanismo para impedir que a população ou um membro do povo se revoltasse contra tal hierarquia, "pois tal é a tendência do homem para o despotismo, que ele procura sem cessar, não só retirar da massa comum sua porção de liberdade, mas ainda usurpar a dos outros." 2

A solução veio logo. Foi a criação das penas, "meios sensíveis e bastante poderosos para comprimir esse espírito despótico que logo tornou a mergulhar a sociedade no seu antigo caos." ${ }^{3}$ Assim, o direito de punir ganhou fundamento, uma vez que serviu para justificar a punição aos que tentavam se valer da porção de liberdade que os outros haviam abdicado em troca do bem-estar comum. Esse direito de punir é concretizado nas leis, que fixam a punição, a pena, de cada delito praticado.

Supõe-se que o cidadão tenha aceito de uma vez por todas, com as leis da sociedade, também aquela que poderá puni-lo. $\mathrm{O}$ criminoso aparece então como um ser juridicamente paradoxal. Ele rompeu o pacto, é, portanto, inimigo da sociedade inteira, mas participa da punição que se exerce sobre ele. O menor crime ataca toda a sociedade; e toda a sociedade - inclusive o criminoso - está presente na menor punição. O castigo penal é então uma função generalizada, coextensiva ao corpo social e a cada um de seus elementos. Coloca-se então o problema da "medida" e da economia do direito de punir. ${ }^{4}$

No ordenamento jurídico brasileiro, o Princípio da Reserva Legal gera a obrigação dos crimes estarem tipificados através de uma lei ordinária decorrente de um processo normativo do Poder Legislativo Federal. Dessa forma, os crimes são escolhas políticas, visto que "crime e criminoso não são entidades absolutas, ou naturais, ou passíveis de ser vistas como algo em si, mas, tão somente, o resultado da vontade do legislador." 5

\footnotetext{
${ }^{2}$ BECCARIA, Cesare. Dos delitos e das penas. 2a ed. São Paulo: Edipro, 2015. p. 24.

${ }^{3}$ Ibid. p. 24.

${ }^{4}$ FOUCAULT, Michel. Vigiar e Punir: nascimento da prisão. 42a ed. Rio de Janeiro: Editora Vozes, 2018. p. 89.

${ }^{5}$ THOMPSON, Augusto. Quem são os criminosos. $2^{\mathrm{a}}$ ed. Rio de Janeiro: Editora Lumen Juris, 2007. p. 47.
} 
Tendo em vista que o poder de produção de leis se encontra na pessoa do legislador, e este, na maioria das vezes, é membro pertencente às elites, estes constroem e manejam os mecanismos legais para manter as diferenças sociais inabaláveis. É por esse motivo que Cesare Beccaria afirma que “... as leis, que deveriam ser convenções feitas livremente entre os homens livres, não foram, na maioria das vezes, mais que o instrumento das paixões da minoria." 6

Faz-se necessário perceber que em um Estado Democrático de Direito, tendo a pessoa do legislador a função de tipificar as infrações e decidir suas penas, o ideal seria que as leis fossem as mais exatas e claras possíveis, visando um atuar igualitário sob todos os membros da sociedade, sem que abram margem para arbitrariedades e interpretações por parte dos mecanismos de repressão penal.

Para ser útil, o castigo deve ter como objetivo as consequências do crime, entendidas como a série de desordens que este é capaz de abrir. A proporção entre a pena e a qualidade do delito é determinada pela influência que o pacto violado tem sobre a ordem social. ${ }^{7}$

Tal afirmação, portanto, está intrinsicamente ligada à lógica do Direito Penal brasileiro ser um Direito Penal do Fato em que se analisa a conduta do suposto autor e, caso ela se amolde a algum tipo penal previsto na legislação, que àquele seja passível uma sanção. Nesse ideal, o cidadão sabe exatamente a punição que lhe vai ser imposta para cada ato que praticar. Nem mais, nem menos.

Com efeito, no caso de um delito, há duas partes: o soberano, que afirma que o contrato social foi violado, e o acusado, que nega essa violação. É preciso pois, que haja entre ambos um terceiro que decida a contestação. Esse terceiro é o magistrado, cujas sentenças devem ser sem apelo e que deve simplesmente pronunciar se há um delito ou não há. ${ }^{8}$

\footnotetext{
${ }^{6}$ BECCARIA, Cesare. Dos delitos e das penas. 2a ed. São Paulo: Edipro, 2015. p. 20.

${ }^{7}$ FOUCAULT, Michel. Vigiar e Punir: nascimento da prisão. $42^{\mathrm{a}}$ ed. Rio de Janeiro: Editora Vozes, 2018. p. 91.

${ }^{8}$ BECCARIA, Cesare. Op. cit., p. 25.
} 
O contratempo que reside nesse aspecto é que se todo o sistema fosse feito à luz do Direito Penal do Fato, ou seja, impossibilitando alguma forma de interpretação acerca do Autor, pessoas que detém o poder se veriam adentrando a malha do sistema penal mais facilmente.

Como, porém, seria possível conciliar o discurso filosófico do iluminismo com os fins pragmáticos a serem extraídos da máquina judicial, sem colocar em demasiada evidência sua atuação interessadamente dirigida? Subordinada a lei a um formalismo inelástico no que concerne ao tratamento igualitário a todas as pessoas, o atuar discriminatório da justiça a deixaria o descoberto diante dos olhos do público. ${ }^{9}$

Dessa forma, como o legislativo decide o que é crime, e sendo a pessoa do legislador pertencente à uma minoria, natural é que todo o suporte de leis aprovadas sejam no sentido de proteger os interesses dessas minorias. Interesses tais que nada mais são do que a manutenção da hierarquia social, o que implica a necessidade de afastar a parcela menos favorecida da população da vida em comunidade.

Uma maneira que se encontrou de implementar essa segregação foi por meio leis abstratas, que proporcionam ao magistrado a possibilidade de, com justificativa de pretensa interpretação, fazer incidir as leis apenas às pessoas que não compartilham da sua realidade. Em consequência, a aprovação pelas casas legislativas de tipos penais cada vez mais obscuros é uma realidade.

Como a direção discriminatória realmente desejada deve ficar escondida atrás de uma cortina de ambiguidades, o emprego de variados e sucessos dialisadores na administração da justiça permite a manutenção, formal, da crença na isonomia. ${ }^{10}$

Surgem, com isso, dois problemas. O primeiro é que, ao se permitir uma necessidade de interpretação por parte do magistrado, essa possa vir a

\footnotetext{
${ }^{9}$ THOMPSON, Augusto. Quem são os criminosos. $2^{\mathrm{a}}$ ed. Rio de Janeiro: Editora Lumen Juris, 2007. p. 35.

${ }^{10}$ THOMPSON, Augusto. Quem são os criminosos. $2^{\mathrm{a}}$ ed. Rio de Janeiro: Editora Lumen Juris, 2007. p. 75.
} 
gerar injustiças; e o segundo diz respeito à população não saber os "inconvenientes de uma ação reprovável." 11 Baseado nessa ideia,

O cidadão que não puder julgar por si mesmo as consequências que devem ter os seus próprios atos sobre a sua liberdade e sobre os seus bens ficará na dependência de um pequeno número de homens depositários e intérpretes das leis. ${ }^{12}$

O "prato cheio" para os magistrados conseguirem a chancela para suas apreciações foi a inclusão, no nosso ordenamento jurídico, de um instituto que demonstra um claro resquício de um Direito Penal do Autor: a possibilidade da análise das circunstancias judiciais do crime - que compõe a primeira fase do procedimento trifásico de aplicação da pena - e contém diversas análises subjetivas, quais sejam: "culpabilidade, antecedentes, conduta social, personalidade do agente, motivos, circunstâncias e consequências do crime, bem como o comportamento da vítima."13

Ora, essa individualização é muito diferente, em natureza, das modulações da pena que se encontravam na jurisprudência antiga. Esta - e nesse ponto ela estava de acordo com a prática penitenciária cristã - usava duas variáveis para ajustar o castigo, as das circunstâncias e as da "intenção". Ou seja, elementos que permitiam classificar o ato em si mesmo. A modulação da pena provinha de uma "casuística" em sentido lato. Mas o que começa a se esboçar agora é uma modulação que se refere ao próprio infrator, à sua natureza, a seu modo de vida e de pensar, a seu passado, à "qualidade" e não mais à intenção de sua vontade. ${ }^{14}$

Dessa forma, dentro desses tipos penais abrangentes e de métodos subjetivos para aplicação da pena, percebe-se uma influência socioeconômica na escolha dos indivíduos que vão chegar a vivenciar a realidade carcerária, uma vez que

\footnotetext{
${ }^{11}$ BECCARIA, Cesare. Dos delitos e das penas. $2^{\mathrm{a}}$ ed. São Paulo: Edipro, 2015. p. 28.

12 Ibid. p. 29.

${ }^{13}$ Art. 59 - O juiz, atendendo à culpabilidade, aos antecedentes, à conduta social, à personalidade do agente, aos motivos, às circunstâncias e consequências do crime, bem como ao comportamento da vítima, estabelecerá, conforme seja necessário e suficiente para reprovação e prevenção do crime: (Redação dada pela Lei n ${ }^{\circ} 7.209$, de 11.7.1984)

I - as penas aplicáveis dentre as cominadas;

II - a quantidade de pena aplicável, dentro dos limites previstos;

III - o regime inicial de cumprimento da pena privativa de liberdade;

IV - a substituição da pena privativa da liberdade aplicada, por outra espécie de pena, se cabível.

${ }^{14}$ FOUCAULT, Michel. Vigiar e Punir: nascimento da prisão. $42^{\mathrm{a}}$ ed. Rio de Janeiro: Editora Vozes, 2018. p. 98.
} 
Nessa linha de pensamento, com efeito, para as instâncias de controle não importa o que se faz (direito penal do fato), mas sim quem faz. Em outros termos, não se pune pela prática do fato, mas sim pela qualidade, personalidade ou caráter de quem faz, num autêntico Direito penal de autor. ${ }^{15}$

Baseado nessa ideia de que apenas as pessoas que portam características do "homem delinquente"16 são mais propensas a serem submetidas a algum tipo de pena, uma vez que os resquícios de um direito autoral no ordenamento jurídico permitem tal segregação, cria-se uma cifra negra da criminalidade, conceito esse explicado por Augusto Thompson na seguinte passagem:

A partir de meados do nosso século, algumas pesquisas lograram evidenciar a existência da discrepância entre o número de crimes constantes das estatísticas oficias e a realidade escondida por trás dele. Observou-se que, embora os índices da ordem formal indiquem existir uma considerável quantidade de infrações, o total dos delitos de fato praticados supera-los largamente. Apenas uma reduzida minoria das violações à lei criminal chega à luz do conhecimento público. À brecha constatada entre os crimes cometidos e os registrados denominou-se "cifra negra da criminalidade", expressão que logo se firmou, enquanto representava fenômeno muito comum. ${ }^{17}$

Partindo dessa concepção, se fez necessário analisar a distribuição desses delitos que são descobertos, ou seja, adentram as estatísticas oficias, para se chegar a conclusão se há algum tipo de característica sempre presente na "etiqueta de criminoso."18 Buscando alguma resposta, o ilustre criminalista percebeu que essa divisão não é um jogo de sorte e azar, sendo facilmente identificável as características e princípios que norteiam essa seleção, o que faz do sistema penal um mecanismo discriminatório.

Por tudo isso, parece sensato reconhecer que há maior vulnerabilidade dos membros das camadas inferiores do que daqueles das camadas superiores quanto a ter seus crimes fulminados pelos raios de luz da ordem formal. ${ }^{19}$

\footnotetext{
${ }^{15}$ BITENCOURT, Cezar Roberto. Falência da pena de Prisão: Causas e Alternativas. $5^{\mathrm{a}}$ ed. São Paulo: Saraiva, 2017. p. 43

16 Ibid. p. 41

${ }^{17}$ THOMPSON, Augusto. Quem são os criminosos. 2a ed. Rio de Janeiro: Editora Lumen Juris, 2007. p. 3.

${ }^{18}$ Ibid. p. 46.

${ }^{19}$ Ibid. p. 64.
} 
Por conseguinte, os dados do Fórum Brasileiro de Segurança Pública revelam que pretos e pardos perfaziam $60,8 \%$ da população carcerária brasileira em 2012. Segundo dados do último Censo Demográfico do IBGE, pretos e pardos representam 55\% da população brasileira, "o que significa que sua proporção na amostra analisada é superior àquela encontrada na população em geral." 20

Cabe observar também que os tipos penais imputados aos apenados referem-se em grande parte a crimes contra o patrimônio, que no total de processos somam 40,9\%. Entre os não reincidentes essa porcentagem diminui para $39,2 \%$. Porém, entre os reincidentes ela cresce e chega a ultrapassar os $50 \%$. Ressalta-se que o crime de furto foi o mais frequente em todas as categorias. ${ }^{21}$

Com leis que possibilitam uma análise da periculosidade do autor, somada ao fato que há impregnado na sociedade a ideia da criminalidade como algo decorrente da pobreza, muito por conta dos números acima elencados, todo mecanismo de repressão penal se organiza para encontrar criminosos em comunidades carentes, fenômeno ao qual se é dado o nome de "Tirocínio Policial"22, e que constrói na prática a cifra negra da criminalidade.

As dinâmicas de segurança pública e de justiça criminal determinarão, assim, o perfil da população brasileira que hoje superlota as prisões: trata-se, em sua maioria, de homens jovens, negros, com baixa escolaridade e renda, detidos em flagrante por crimes patrimoniais ou tráfico de drogas.

$(\ldots)$

${ }^{20}$ INSTITUTO DE PESQUISA ECONÔMICA APLICADA - Reincidência Criminal no Brasil. Relatório de Pesquisa. p. 24. Disponível em:

<http://www.ipea.gov.br/portal/images/stories/PDFs/relatoriopesquisa/150611_relatorio_reinciden cia_criminal.pdf $>$. Acesso em: 25 ago. 2018.

${ }^{21}$ Ibid. p. 2.

${ }^{22}$ MINISTÉRIO DA JUSTIÇA/DEPARTAMENTO PENITENCIÁRIO NACIONAL - Modelo de gestão para política prisional. p. 25. Disponível em: < http://www.justica.gov.br/modelo-degestao_documento-final.pdf> . Acesso em: 15 set. 2018. 
Enquanto corporação e policiamento ostensivo, as policiais militares ocupam a linha de frente das políticas de segurança pública. Operando a partir de um princípio de suspeição, ou seja, da criação de tipos de indivíduos suspeitos, esta primeira "camada" do enfrentamento À violência elege o perfil prioritário do indivíduo que será ou não alvo da abordagem policial. ${ }^{23}$

Compreende-se, por tais circunstâncias, haver muito mais probabilidade de serem os delitos dos miseráveis "vistos" pela polícia do que aqueles perpetrados pela gente de posição social mais elevada. ${ }^{24}$

De forma lógica, percebe-se que por tais circunstância existe uma maior possibilidade de os delitos cometidos pelas pessoas de classes sociais inferiores serem descobertos pela polícia e adentrarem a ordem formal das estatísticas. Em decorrência, cria-se um ciclo vicioso, em que os discursos criminológicos, tendo por base os resultados de pesquisas empíricas feitas apenas em penitenciárias, e, portanto, baseados em números que afirmam que os presos são na sua quase totalidade, de classes inferiores, acabam por, de forma "falaciosa e inconsistente" 25 corroborar a ideia de que a criminalidade é decorrente da pobreza, vez que não aludem à cifra negra da criminalidade.

À medida que a biografia do criminoso acompanha na prática penal a análise das circunstancias, quando se trata de medir o crime, vemos os discursos penal e psiquiátrico confundirem suas fronteiras; e ai, em seu ponto de junção, forma-se aquela noção de individuo "perigoso" que permite estabelecer uma rede de causalidade na escala de uma biografia indireta e estabelecer um veredicto de punição-correção. ${ }^{26}$

Que o enxerto da prisão no sistema penal não tenha acarretado reação violenta da rejeição se deve sem dúvida a muitas razões. Uma delas é que, ao fabricar a delinquência, ela deu à justiça criminal um campo unitário de objetos, autentificado por "ciência" e que assim the permitiu funcionar num horizonte geral de "verdade".

Com isso, a pretensa ciência satisfaz os dogmas das classes dominantes, que com um argumento de base científica acabam por querer, mais ainda, os "delinquentes" separados da convivência social. Como afirma

\footnotetext{
${ }^{23}$ Ibid. p. 23-24.

${ }^{24}$ THOMPSON, Augusto. Quem são os criminosos. $2^{\mathrm{a}}$ ed. Rio de Janeiro: Editora Lumen Juris, 2007. p. 62.

${ }^{25}$ Ibid. p. 20

${ }^{26}$ FOUCAULT, Michel. Vigiar e Punir: nascimento da prisão. $42^{\mathrm{a}}$ ed. Rio de Janeiro: Editora Vozes, 2018. p. 246.

${ }^{27}$ Ibid. p. 249
} 
Rubens Casara, juiz de direito, no documentário "Imparcialidade ou Cegueira: um estudo sobre prisões provisórias e alternativas penais", elaborado pelo Instituto de Estudos da Religião (ISER):

O sistema de justiça criminal no Brasil como em todo o mundo, apresenta uma série de distorções. Ele não ressocializa, ele não evita novos crimes. Por outro lado, a funcionalidade real desse sistema qual é? É potencializar a exclusão, exercer um controle social sobre a população indesejada. ${ }^{28}$

Percebe-se, assim, como o sistema penitenciário está propício a receber apenas uma parcela social, a qual a minoria não interessa manter em liberdade. Dessa forma, a criação da prisão-sanção como forma de controle social, visando proteger a ordem econômica, deixa claro que é impossível se ressocializar o indivíduo através da pena privativa de liberdade, vez que ela não busca esse fim. Por esse motivo,

É preciso reconhecer que a pena privativa de liberdade é um instrumento, talvez dos mais graves, com que conta o Estado para preservar a vida social de um determinado grupo. ${ }^{29}$

Passa-se, então, a fazer uma análise dos três objetivos oficiais da pena e qual a importância atribuída a cada um deles.

\subsection{O tripé dos objetivos da pena e sua ruína inevitável}

Ao chegar às penitenciárias os indivíduos que a sociedade livre visa dominar e reprimir, as que "jazem no limbo social" 30 a sanção penal em nosso ordenamento jurídico visa formalmente à três objetivos ${ }^{31}$ :

1) a punição retributiva do mal causado pelo delinquente;

\footnotetext{
${ }^{28}$ IMPARCIALIDADE OU CEGUEIRA: Um estudo sobre prisões provisórias e alternativas penais. Instituto de Estudos da Religião (ISER). Disponível em:

<https://www.youtube.com/watch?v=a7G5tSH6COQ>. 6min38-6min58. Acesso em: 18 set. 2018.

${ }^{29}$ BITENCOURT, Cezar Roberto. Falência da pena de Prisão: Causas e Alternativas. $5^{\mathrm{a}}$ ed. São

Paulo: Saraiva, 2017. p. 163

${ }^{30}$ THOMPSON, Augusto. Quem são os criminosos. $2^{\mathrm{a}}$ ed. Rio de Janeiro: Editora Lumen Juris, 2007. p. 42.

${ }^{31}$ THOMPSON, Augusto. A questão penitenciária. $5^{\mathrm{a}}$ ed. Rio de Janeiro: Editora Forense, 2002. p. 3.
} 
2) a prevencão da prática de novas infrações, através da intimidação do condenado e de pessoas potencialmente criminosas;

3) a ressocialização do preso, no sentido de transformá-lo criminoso em não criminoso.

Em tese, dentre esses três, o que mais se consagra como a meta a ser atingida é a ressocialização do condenado. Ao mesmo tempo, os outros dois objetivos (retributivo e preventivo) não podem ser excluídos frente ao de ressocialização, uma vez que tal disposição não conta com amparo legal.

Dentre os escopos da pena carcerária, os fins de punição e intimidação permanecem intocados, inexistindo regra alguma a autorizar possam ser desprezados, em maior ou menor extensão, se isso for necessário, em benefício da atividade reeducativa. ${ }^{32}$

O choque entre princípios, finalidades e fundamentos absolutamente distintos era inevitável. O que poderia resultar aconselhável em termos de prevenção geral poderia contrariar o princípio da culpabilidade ou da proporcionalidade, e ambos poderiam, inclusive, colidir coma s previsões da prevenção especial. Os problemas decorrentes de tudo isso se concretizam na hora de cominação penal ou da determinação judicial e penitenciaria da pena. ${ }^{33}$

A problemática em questão é o fato desses três pilares não poderem coexistir sem que leve ao fracasso de um deles, uma vez que "oferecem espantosa combinação." 34

Punir é castigar, fazer sofrer. Para punir um homem retributivamente é preciso injuriálo. A intimidação, a ser obtida pelo castigo, demanda que este seja apto a causar terror. Ora, tais condições são reconhecidamente impeditivas de levar ao sucesso uma ação pedagógica, pois para reformar um homem é preciso melhorá-lo e os homens não são melhoráveis através das injúrias. ${ }^{35}$

Tal ruína tem seu fracasso na própria razão de ser. O que oficialmente seria um tripé que fortaleceria o instituto da pena, acaba se tornando na realidade três vetores, uma vez que não se autossustentam, podendo se dizer,

\footnotetext{
${ }^{32}$ Ibid. p. 4

${ }^{33}$ BITENCOURT, Cezar Roberto. Falência da pena de Prisão: Causas e Alternativas. $5^{\mathrm{a}}$ ed. São Paulo: Saraiva, 2017. p. 166

${ }^{34}$ THOMPSON, Augusto. Op. Cit., p. 22.

${ }^{35}$ THOMPSON, Augusto. A questão penitenciária. $5^{\mathrm{a}}$ ed. Rio de Janeiro: Editora Forense, 2002. p. 6.
} 
inclusive, que estão colocados em sentidos opostos. E, tendo um total de uma força " $X$ " para se aplicar (fazendo uma analogia com os recursos do Estado destinados a esses fins), acaba se escolhendo apenas um vetor no qual aplicala, enquanto o outro é proporcionalmente reduzido.

Em face da impossibilidade de estabelecer uma política operacional coerente, para qual todos os fins formais e informais pudessem ser atingidos concomitantemente, só resta sacrificar uns em favor dos outros. ${ }^{36}$

Assim, como a sociedade acredita que a criminalidade se reduz quando “os criminosos” estão contidos, e para a maioria a prisão é a única forma de se fazê-lo, o sistema penal, a fim de não colapsar perante as expectativas sociais, acaba por privilegiar os vetores retributivos e preventivos em detrimento ao de ressocialização.

Dessa forma, destaca-se:

Para aliviar o sentimento de fracasso decorrente da crua constatação da impossibilidade dos vários objetivos propostos à administração penitenciária, há um único recurso: redefinir o alvo prestigiado como capital, transmutando-o de readaptação do condenado à vida para adaptação do preso à vida intramuros. ${ }^{37}$

Tal é o grau de importância emprestado a esses meios, tidos como os únicos côngruos para atingir as metas propostas, que a sociedade os eleva uma posição de prevalência, relativamente aos próprios fins - ou seja: os meios transformam-se em fins e, mais, em fins prioritários. Disso resulta que os controles informais do mundo livre dirigem-se, predominantemente, no sentido de fiscalizar a satisfação dos alvos (normalmente meios) segurança e disciplina, ao mesmo passo em que afrouxam no que tange aos objetivos oficialmente reconhecidos. ${ }^{38}$

Exemplo claro dessa redefinição de alvo se encontra "endossado até pela lei." ${ }^{39}$ É o caso de que, para concessão do livramento condicional, um dos requisitos é o "bom comportamento durante a vida carcerária." 40 Essa

\footnotetext{
${ }^{36}$ THOMPSON, Augusto. Quem são os criminosos. 2a ed. Rio de Janeiro: Editora Lumen Juris, 2007. p. 100.

${ }^{37}$ Ibid. p. 100.

${ }^{38}$ THOMPSON, Augusto. A questão penitenciária. 5a ed. Rio de Janeiro: Editora Forense, 2002. p. 9.

${ }^{39}$ THOMPSON, Augusto. A questão penitenciária. 5a ed. Rio de Janeiro: Editora Forense, 2002. p. 11.

${ }^{40}$ Art. 83 - O juiz poderá conceder livramento condicional ao condenado a pena privativa de liberdade igual ou superior a 2 (dois) anos, desde que: (Redação dada pela Lei $n^{\circ} 7.209$, de 11.7.1984)
} 
condição significa nada mais do que uma adaptação a vida prisional, que em termos jurídicos é equiparado com uma adaptação a vida livre. Na realidade, porém, esse bom comportamento nada tem em comum com uma possível "ressocialização", visto que a vida, os costumes e as regras internas da penitenciária diferem extremamente das da sociedade.

A boa conduta foi aqui imaginada como um indício de readaptação social, mas é bastante claro que o comportamento do condenado no ambiente carcerário pode não ter qualquer relação com a sua recuperação social. Trata-se de ambiente autoritário e anormal, que deforma a personalidade. ${ }^{41}$

Em consequência, o tratamento do preso para que ele se readapte a sociedade que, relembra-se, é o principal objetivo da pena, acaba cedendo lugar à chamada "prisonização". Tal efeito, nomeado por Donald Clemmer em seu estudo The Prision Community “indica a adoção, em maior ou menor grau, do modo de pensar, dos costumes, dos hábitos - da cultura geral da penitenciária" 42 e decorre do fato de que "a penitenciária é uma sociedade

I - cumprida mais de um terço da pena se o condenado não for reincidente em crime doloso e tiver bons antecedentes; (Redação dada pela Lei no 7.209 , de 11.7.1984)

II - cumprida mais da metade se o condenado for reincidente em crime doloso; (Redação dada pela Lei $\mathrm{n}^{\mathrm{o}}$ 7.209, de 11.7.1984)

III - comprovado comportamento satisfatório durante a execução da pena, bom desempenho no trabalho que lhe foi atribuído e aptidão para prover à própria subsistência mediante trabalho honesto; (Redação dada pela Lei no 7.209, de 11.7.1984)

IV - tenha reparado, salvo efetiva impossibilidade de fazê-lo, o dano causado pela infração; (Redação dada pela Lei n ${ }^{\circ} 7.209$, de 11.7.1984)

V - cumprido mais de dois terços da pena, nos casos de condenação por crime hediondo, prática da tortura, tráfico ilícito de entorpecentes e drogas afins, e terrorismo, se o apenado não for reincidente específico em crimes dessa natureza. (Incluído pela Lei no 8.072, de 25.7.1990)

$\mathrm{V}$ - cumpridos mais de dois terços da pena, nos casos de condenação por crime hediondo, prática de tortura, tráfico ilícito de entorpecentes e drogas afins, tráfico de pessoas e terrorismo, se o apenado não for reincidente específico em crimes dessa natureza. (Incluído pela Lei $n^{\circ} 13.344$, de 2016) (Vigência)

Parágrafo único - Para o condenado por crime doloso, cometido com violência ou grave ameaça à pessoa, a concessão do livramento ficará também subordinada à constatação de condições pessoais que façam presumir que o liberado não voltará a delinqüir. (Redação dada pela Lei $n^{\circ} 7.209$, de 11.7.1984)

${ }^{41}$ FRAGOSO, Heleno Cláudio. Lições de Direito Penal, v.1, p. 390 apud BITENCOURT, Cezar

Roberto. Falência da pena de Prisão: Causas e Alternativas. $5^{\mathrm{a}}$ ed. São Paulo: Saraiva, 2017. p. 436

${ }^{42}$ THOMPSON, Augusto. A questão penitenciária. 5a ed. Rio de Janeiro: Editora Forense, 2002. p. 23. 
dentro de uma sociedade, uma vez que nela foram alteradas, drasticamente, numerosas feições da comunidade livre." 43

Dessa forma, coagido a seguir preceitos de disciplina diferentes e, muitas vezes contrários em diversos aspectos dos que vivia até então, o preso se vê, por questão de sobrevivência, forçado a se adaptar, esquecendo-se de como se readaptar à sociedade. "A prisonização é um processo criminológico que leva a uma meta diametralmente oposta à que pretende alcançar o objetivo ressocializador". ${ }^{4}$

Percebe-se, portanto, que ao se transmutar o vetor principal da penitenciária para os fins de segurança e disciplina, a sociedade livre atinge o seu objetivo: manter o preso, preso. Portanto, por uma adaptação à prisão, e desadaptação da vida aqui fora, bem como por uma falta de tratamento profissional, os presos estão fadados a reincidir.

Realiza-se, a seguir, a análise da realidade carcerária brasileira, atribuindo à alguns fatores a razão desta se destoar tanto do modo de vida "aqui fora", enfatizando como a mudança na importância dos vetores altera essa realidade. Vislumbra-se também a oportunidade de se fazer uma comparação desta frente à Lei de Execuções Penais e à Constituição Federal.

\footnotetext{
${ }^{43}$ THOMPSON, Augusto. A questão penitenciária. $5^{\mathrm{a}}$ ed. Rio de Janeiro: Editora Forense, 2002. p. 22.

${ }^{44}$ BITENCOURT, Cezar Roberto. Falência da pena de Prisão: Causas e Alternativas. $5^{\mathrm{a}}$ ed. São Paulo: Saraiva, 2017. p. 204
} 


\title{
Capítulo II - Uma análise da Lei de Execuções Penais (LEP) frente à realidade do cárcere
}

\author{
"Questiona-se a validade da pena de prisão no campo da teoria, dos \\ princípios, dos fins ideais ou abstratos da privação de liberdade e se tem \\ deixado de lado, em plano muito inferior, o aspecto principal da pena \\ privativa de liberdade, que é o da sua execução" \\ $[\ldots]$ \\ "Definitivamente, deve-se mergulhar na realidade e abandonar, de uma \\ vez por todas, o terreno dos dogmas, das teorias, do dever-ser e da \\ interpretação das normas. ${ }^{145}$
}

Pretende-se nessa seção fazer uma análise de como a impossibilidade de coexistência entre os três objetivos da pena influenciam a realidade carcerária, seja no tratamento que o preso recebe em suas diversas vertentes, seja na expectativa que a sociedade coloca no encarceramento, e, como, por consequência, acabam por legitimar a falha na prestação do serviço de ressocialização do preso.

A Lei de Execuções Penais (LEP), lei 7210/84, positiva os objetivos da pena em seu artigo $10^{46}$, afirmando que a assistência ao preso visa "prevenir o crime e orientar o retorno à convivência em sociedade". O artigo seguinte ${ }^{47}$ demonstra seis tipos de assistências para dar suporte ao preso, quais sejam: material, à saúde, jurídica, educacional, social e religiosa.

Cada uma dessas vertentes comporta uma seção ao longo da Lei 7210/1984, em que o assunto é tratado mais especificamente, o que gera,

\footnotetext{
${ }^{45}$ BITENCOURT, Cezar Roberto. Falência da pena de Prisão: Causas e Alternativas. $5^{\mathrm{a}}$ ed. São Paulo: Saraiva, 2017. p. 175-176

${ }^{46}$ Art. 10. A assistência ao preso e ao internado é dever do Estado, objetivando prevenir o crime e orientar o retorno à convivência em sociedade.

Parágrafo único. A assistência estende-se ao egresso.

${ }^{47}$ Art. 11. A assistência será:

I - material;

II - à saúde;

III - jurídica;

IV - educacional;

V - social;

$\mathrm{VI}$ - religiosa.
} 
portanto, um corpo legal repleto de direitos ao preso e egresso. Os artigos 40 à $43^{48}$ e o artigo $83^{49}$, porém, dão um breve introito de como (em tese) deve se estruturar a realidade prisional brasileira.

\footnotetext{
${ }^{48}$ Art. 40 - Impõe-se a todas as autoridades o respeito à integridade física e moral dos condenados e dos presos provisórios.

Art. 41 - Constituem direitos do preso:

I - alimentação suficiente e vestuário;

II - atribuição de trabalho e sua remuneração;

III - Previdência Social;

IV - constituição de pecúlio;

$\mathrm{V}$ - proporcionalidade na distribuição do tempo para o trabalho, o descanso e a recreação;

VI - exercício das atividades profissionais, intelectuais, artísticas e desportivas anteriores, desde que compatíveis com a execução da pena;

VII - assistência material, à saúde, jurídica, educacional, social e religiosa;

VIII - proteção contra qualquer forma de sensacionalismo;

IX - entrevista pessoal e reservada com o advogado;

$X$ - visita do cônjuge, da companheira, de parentes e amigos em dias determinados;

XI - chamamento nominal;

XII - igualdade de tratamento salvo quanto às exigências da individualização da pena;

XIII - audiência especial com o diretor do estabelecimento;

XIV - representação e petição a qualquer autoridade, em defesa de direito;

$\mathrm{XV}$ - contato com o mundo exterior por meio de correspondência escrita, da leitura e de outros meios de informação que não comprometam a moral e os bons costumes.

XVI - atestado de pena a cumprir, emitido anualmente, sob pena da responsabilidade da autoridade judiciária competente. (Incluído pela Lei $\mathrm{n}^{\circ} 10.713$, de 2003)

Parágrafo único. Os direitos previstos nos incisos V, X e XV poderão ser suspensos ou restringidos mediante ato motivado do diretor do estabelecimento.
}

Art. 42 - Aplica-se ao preso provisório e ao submetido à medida de segurança, no que couber, o disposto nesta Seção.

Art. 43 - É garantida a liberdade de contratar médico de confiança pessoal do internado ou do submetido a tratamento ambulatorial, por seus familiares ou dependentes, a fim de orientar e acompanhar o tratamento.

Parágrafo único. As divergências entre o médico oficial e o particular serão resolvidas pelo Juiz da execução.

${ }^{49}$ Art. 83. O estabelecimento penal, conforme a sua natureza, deverá contar em suas dependências com áreas e serviços destinados a dar assistência, educação, trabalho, recreação e prática esportiva. $\S 1^{\circ}$ Haverá instalação destinada a estágio de estudantes universitários. (Renumerado pela Lei $n^{\circ}$ 9.046, de 1995)

$\S 2^{\circ}$ Os estabelecimentos penais destinados a mulheres serão dotados de berçário, onde as condenadas possam amamentar seus filhos.

(Incluído pela Lei $\mathrm{n}^{\circ}$ 9.046, de 1995)

$\S 20$ Os estabelecimentos penais destinados a mulheres serão dotados de berçário, onde as condenadas possam cuidar de seus filhos, inclusive amamentá-los, no mínimo, até 6 (seis) meses de idade. (Redação dada pela Lei no 11.942 , de 2009)

$\S 3$ o Os estabelecimentos de que trata o § 20 deste artigo deverão possuir, exclusivamente, agentes do sexo feminino na segurança de suas dependências internas. (Incluído pela Lei $\mathrm{n}^{\circ} 12.121$, de 2009).

$\S 4$ o Serão instaladas salas de aulas destinadas a cursos do ensino básico e profissionalizante. (Incluído pela Lei ${ }^{\circ} 12.245$, de 2010)

§ 5o Haverá instalação destinada à Defensoria Pública. (Incluído pela Lei nº 12.313, de 2010). 
Nos primeiros, a LEP afirma: "Impõe-se a todas as autoridades o respeito à integridade física e moral dos condenados e dos presos provisórios". No dispositivo subsequente, expõe um rol não taxativo de 16 (dezesseis) direitos dos presos afirmando, logo após, que esses se estendem ao preso provisório e ao submetido à medida de segurança. $\mathrm{O}$ último dispositivo mencionado é um comando normativo afirmando que os estabelecimentos penais devem fornecer espaços de assistência, trabalho, educação, recreação e prática esportiva.

A partir desse panorama geral, optou-se, no presente trabalho, dar enfoque a 5 assistências que são consideradas essenciais para um tratamento humano e digno, e que, de todas as formas, estão interligadas às outras aludidas pela legislação. São elas: a assistência material, educacional e laborativa, à saúde, social e ao egresso.

Utilizou-se, para fins de comparação entre a realidade e a normativa legal, dados encontrados no Modelo de Gestão criado pelo Ministério da Justiça em parceria com o Departamento Penitenciário Nacional (DEPEN), que, segundo a LEP ${ }^{50}$, é o órgão com atribuição de "acompanhar, fiscalizar, inspecionar, assistir técnica e financeiramente a execução da Política Penitenciária, além de colaborar na formação e aprimoramento dos quadros

\footnotetext{
${ }^{50}$ Art. 72. São atribuições do Departamento Penitenciário Nacional:

I - acompanhar a fiel aplicação das normas de execução penal em todo o Território Nacional;

II - inspecionar e fiscalizar periodicamente os estabelecimentos e serviços penais;

III - assistir tecnicamente as Unidades Federativas na implementação dos princípios e regras estabelecidos nesta Lei;

IV - colaborar com as Unidades Federativas mediante convênios, na implantação de estabelecimentos e serviços penais;

V - colaborar com as Unidades Federativas para a realização de cursos de formação de pessoal penitenciário e de ensino profissionalizante do condenado e do internado.

VI - estabelecer, mediante convênios com as unidades federativas, o cadastro nacional das vagas existentes em estabelecimentos locais destinadas ao cumprimento de penas privativas de liberdade aplicadas pela justiça de outra unidade federativa, em especial para presos sujeitos a regime disciplinar. (Incluído pela Lei n ${ }^{\circ} 10.792$, de 2003)

Parágrafo único. Incumbem também ao Departamento a coordenação e supervisão dos estabelecimentos penais e de internamento federais.
} 
de pessoal penitenciário dos Estados" ${ }^{51}$. bem como o Levantamento Nacional de Informações Penitenciárias (INFOPEN) e o Relatório de Reincidência Criminal no Brasil, feito pelo Instituto de Pesquisa Econômica Aplicada (IPEA)

Cabe, porém, antes de adentramos na análise de cada uma das assistências supramencionadas, percebermos como a incongruência dos objetivos da pena, por si só, já afetam a possibilidade de alcance desses, simplesmente por um problema interno: a relação disfuncionada entre o pessoal da guarda e o pessoal de tratamento, como se verá adiante.

\subsection{A incongruências dos objetivos da pena e a sua reprodução dentro da penitenciária}

"A prisão em seu todo é incompativel com toda essa técnica da penaefeito, da pena-representação, da pena-função geral, da pena-sinal e discurso. Ela é a escuridão, a violência e a suspeita" ${ }^{52}$

Transmutando os três vetores anteriormente analisados em sua face abstrata, passa-se a fazer uma análise concreta de suas aplicações na vida cotidiana de um recluso. A incongruência, como demonstra Thompson na seguinte passagem, não só persiste, como aumenta, quando observamos esse novo quadro.

A penitenciária deve: 1) punir; 2) intimidar; 3) regenerar. Espera-se do guarda, por conseguinte: fazer os presos sofrerem (metas 1 e 2), e procurar ser amigo do interno, lidando com ele como se fosse um paciente ou um aluno (meta 3 ).

$\mathrm{Ou}$, particularizando, deve, concomitantemente: trata-lo como um indivíduo único, mas conta-lo, como um objeto, no momento dos "conferes"; respeitá-lo, como um ser dotado de prerrogativas inalienáveis, dentre as quais ressalta o direito à intimidade, porém revistar-lhe, frequentemente, o cubículo, remexendo-lhes os objetos pessoais, e vistoriar as roupas que está vestindo, inspecionando-o, até mesmo, nas partes mais íntimas do corpo; captar-lhe a confiança e trancá-lo a chave numa cela. ${ }^{53}$

\footnotetext{
${ }^{51}$ MINISTÉRIO DA JUSTIÇA/DEPARTAMENTO PENITENCIÁRIO NACIONAL - Modelo de gestão para política prisional. p. 397. Disponível em: < http://www.justica.gov.br/modelo-degestao_documento-final.pdf> . Acesso em: 15 set. 2018

${ }^{52}$ FOUCAULT, Michel. Vigiar e Punir: nascimento da prisão. $42^{\mathrm{a}}$ ed. Rio de Janeiro: Editora Vozes, 2018. p. 113.

${ }^{53}$ THOMPSON, Augusto. A questão penitenciária. $5^{\mathrm{a}}$ ed. Rio de Janeiro: Editora Forense, 2002. p. 41.
} 
Diante do demonstrado que frente à ruína dos objetivos oficias da pena os vetores retributivos e preventivos acabam ganhando força, por coexistir a ideologia social de que os delinquentes têm características naturais que são impossíveis de serem transformadas, devendo estes permanecerem presos, a segurança e a disciplina dos detentos são tratadas como ponto principal na aplicação da sanção penal. Dessa forma,

consciente de que um descuido, no que concerne à segurança e disciplina, redundará na sujeição a sanções, enquanto que um malogro, no que respeita à intimidação e recuperação, passará in albis, a administração penitenciária vê-se compelida a enfatizar o caráter custodial do confinamento carcerário, tendendo a exercer uma vigilância severa sobre os internos. A melhor maneira de prevenir evasões e desordens é impor um regime de asfixiante cerceamento à autonomia do recluso. A rigidez da disciplina-preço alto que se paga pela segurança-traduz-se na supressão do autodiscernimento, da responsabilidade pessoal, da iniciativa do paciente. ${ }^{54}$

No dia a dia da penitenciária, portanto, o próprio sistema interno se torna uma barreira aos mecanismos de tratamento do preso. Várias razões levam a isso. Contudo, todas decorrem de uma premissa maior centrada no impasse entre o pessoal de tratamento e o pessoal da guarda de exercer com produtividade as suas funções. Importante analisar, primeiro, a premissa geral, para depois chegar aos percalços decorrentes dela.

A premissa geral é simples: o trabalho da guarda e o trabalho do pessoal de tratamento são absolutamente incompatíveis. Isso porque, como é impossível se atingir os três objetivos concomitante, o primeiro grupo se vê forçado a aderir apenas os de segurança e disciplina, enquanto o segundo foca na ressocialização.

Essa divisão de funções inconciliáveis entre si gera uma "barreira sutil e impenetrável entre o staff custodiador e os especialistas de terapia"55, explicada na seguinte passagem:

\footnotetext{
${ }^{54}$ THOMPSON, Augusto. A questão penitenciária. $5^{\mathrm{a}}$ ed. Rio de Janeiro: Editora Forense, 2002. p. 43.

${ }^{55}$ Ibid. p. 54
} 
Os psicólogos alegam que sem uma atmosfera permissiva ficam impossibilitados de obter resultados positivos no seu campo. Os guardas retrucam que, se o ritmo que imprimem à cadeia for quebrado, pelo rompimento do esquema de estreita vigilância sobre os presos, a instituição se transformará num caos. Aqueles requerem tratamento especial para cada paciente sob seus cuidados, de acordo com a psicóloga particular de cada um; estes respondem que, se a rotina prisional for perturbada, com a adoção de regimes diversos para cada indivíduo, a disciplina ficará irremediavelmente comprometida. ${ }^{56}$

Além disso, na hipótese de um tratamento específico e determinado a cada preso em decorrência de suas condições individuais e psicológicas, haveria a necessidade de diversas consultas e aulas, o que retiraria os presos de suas celas e os levaria aos diversos espaços da penitenciária. Não bastasse isso, os que demonstrassem uma boa condição receberiam privilégios, tais como possibilidade de locomoção, área de lazer por mais tempo, entre outras atividades.

Essa maior circulação de internos é inadmissível para os guardas, que, para exercerem sua função, o melhor dos cenários é ter os encarcerados no mesmo lugar a maior parte do tempo. Caso contrário, seriam obrigados a os seguir por todo o tempo e planejar métodos de transferência dentro do presídio. o que soa para eles como maior possibilidade de fugas e caos.

Dessa disputa interna só existe um vencedor possível, e esse é decidido pelo diretor da penitenciária, que pressionado pela sociedade acaba por ceder e privilegiar os vetores "meios" (preventivo e retributivo) sob o vetor "fim" (ressocialização).

Os atritos vão desaguar no gabinete do diretor (só quem dirigiu uma prisão pode avaliar a infinidade de casos oriundos dessa guerra surda). E ele, contrariado ou não, por subterfúgios ou diretamente, é forçado a apoiar os setores de segurança e disciplina. ${ }^{57}$

Os números confirmam a realidade acima aludida por Augusto Thompson. De acordo com o Levantamento Nacional de Informações Penitenciarias, realizado pelo INFOPEN, com última atualização em junho

\footnotetext{
${ }^{56}$ Ibid. p. 54

${ }^{57}$ THOMPSON, Augusto. Quem são os criminosos. $2^{\mathrm{a}}$ ed. Rio de Janeiro: Editora Lumen Juris, 2007. p. 55-56.
} 
de 2016, os servidores responsáveis pela atividade de custodia de pessoas representam $74 \%$ de todos os profissionais do sistema, somando 78.163 pessoas. Os servidores lotados em cargos administrativos aparecem em segundo lugar, somando 8.900 pessoas (ou $8 \%$ do total de servidores). Todas as categorias ligadas à saúde (que compreende os médicos, enfermeiros, dentistas, ginecologistas, clínicos, psiquiatras e demais especialidades) representam, juntas, $6 \%$ dos servidores do sistema penal. Os advogados e assistentes sociais somam, cada um, $1 \%$ do quadro de servidores. Por fim, as categorias ligadas à educação (que compreende os pedagogos e professores), somam $3 \%$ dos funcionários do sistema (ou 3.124 pessoas) ${ }^{58}$.

Como se percebe, a estrutura penitenciária nos leva a crer que se trata de um regime totalitário, em que a população, regida sob regras, é privada de sua liberdade de locomoção para resguardar a paz e evitar massacres. Nesse cenário, torna-se impossível qualquer tipo de assistência ao preso, uma vez que o espaço é tomado por uma eterna desconfiança de todos os lados: entre servidores, guardas e equipe de tratamento.

O que se percebe no interior de muitos estabelecimentos prisionais, portanto, é um conflito permanente entre a garantia dos direitos e a propensão à contenção total das pessoas custodiadas, evitando-se ao máximo sua movimentação interna pelos ambientes prisionais. ${ }^{59}$

Partindo da premissa geral exposta de que, por si só, os trabalhos dos guardas e do pessoal de tratamento são incongruentes, é possível analisar a realidade do presídio e perceber como todas as violações à Lei de Execuções Penais estão intrinsicamente ligadas ao fato já exaustivamente tratado da incongruência dos objetivos da pena.

\footnotetext{
${ }^{58}$ MINISTÉRIO DA JUSTIÇA E SEGURANÇA PÚBLICA/Departamento Penitenciário Nacional- Levantamento Nacional de Informações Penitenciárias (INFOPEN). p. 46. Disponível em: 〈http://depen.gov.br/DEPEN/depen/sisdepen/infopen/relatorio_2016_22-11.pdf >. Acesso em: 14 out. 2018.

${ }^{59}$ MINISTÉRIO DA JUSTIÇA/DEPARTAMENTO PENITENCIÁRIO NACIONAL - Modelo de gestão para política prisional. p. 150. Disponível em: < http://www.justica.gov.br/modelo-degestao_documento-final.pdf $>$. Acesso em: 15 set. 2018
} 


\title{
2.2 A superlotação dos presídios sob o viés da assistência material
}

A LEP prevê o direito do preso de obter uma assistência material, elencada em seu artigo 11, inciso $\mathrm{I}^{60}$. Especificando uma das vertentes desse suporte, o artigo 85 afirma que "O estabelecimento penal deverá ter lotação compatível com a sua estrutura e finalidade." ${ }^{61}$, enquanto o artigo $88^{62}$ prevê normas concretas desse amparo, afirmando que a cela deverá conter dormitório, aparelho sanitário e lavatório, com área mínima de 6,00m2 e salubridade, insolação e condicionamento térmico adequados à existência humana.

\begin{abstract}
Além disso,
os requisitos mínimos para que um estabelecimento mereça ser classificado como penitenciaria são, até mesmo por disposição legal, propiciar isolamento aos internos durante o repouso noturno - o que demanda esteja este provido de cubículos individuais - e oferecer trabalho remunerado aos presos - o que impõe seja-lhes permitido circular pela casa, ou, pelo menos, o que repele a ideia de ficarem trancafiados dia e noite. ${ }^{63}$
\end{abstract}

A superlotação dos presídios é um dos principais problemas da realidade carcerária, não só brasileira, mas da maioria dos países ocidentais, além de China, Índia e outras nações ${ }^{64}$. Isso porque a quantidade de pessoas

\footnotetext{
60 Art. 11. A assistência será:

I - material;

II - à saúde;

III - jurídica;

IV - educacional;

$\mathrm{V}$ - social;

VI - religiosa.

61 Art. 85. O estabelecimento penal deverá ter lotação compatível com a sua estrutura e finalidade. Parágrafo único. O Conselho Nacional de Política Criminal e Penitenciária determinará o limite máximo de capacidade do estabelecimento, atendendo a sua natureza e peculiaridades.

62 Art. 88. O condenado será alojado em cela individual que conterá dormitório, aparelho sanitário e lavatório.

Parágrafo único. São requisitos básicos da unidade celular:

a) salubridade do ambiente pela concorrência dos fatores de aeração, insolação e condicionamento térmico adequado à existência humana;

b) área mínima de $6,00 \mathrm{~m} 2$ (seis metros quadrados).

${ }^{63}$ THOMPSON, Augusto. A questão penitenciária. $5^{\mathrm{a}}$ ed. Rio de Janeiro: Editora Forense, 2002.

p. 103

${ }^{64}$ MINISTÉRIO DA JUSTIÇA/DEPARTAMENTO PENITENCIÁRIO NACIONAL - Modelo de gestão para política prisional. p. 13. Disponível em: < http://www.justica.gov.br/modelo-degestao_documento-final.pdf >. Acesso em: 15 set. 2018
} 
que se veem adentrando a malha penal é consideravelmente maior do que a capacidade que os presídios podem suportar. Soma-se a isso o fato de que não é possível frear o trabalho da polícia na investigação dos crimes ou o acontecimento desses, o que impossibilita a redução no contingente de entrada no sistema.

Dessa forma, "pouco importa seja "x" a capacidade ideal; ainda que o fornecimento se apresente na ordem de $\mathrm{x}^{2}$ ou $\mathrm{x}^{10}$, terá de ser consumido, seja em que condições for, haja o que houver."65. Essa impossibilidade de controle policial/jurisdicional transmuta à penitenciária o dever de acolher esse preso, independentemente de sua capacidade populacional já ter sido atingida ou não.

Se a área pode suportar cinquenta alojamentos, com dez presos em cada um, tornase viável nela recolher uma população de mil e quinhentas ou duas mil pessoas, se, em vez de dividi-la em compartimentos, a autoridade se limita a cerca-la com arame farpado, deixando que os residentes se amontoem no interior, dormindo no chão puro (como ocorria no antigo Galpão, no Rio-hoje instituto Presídio Evaristo de Morais - até 1967). Se o número de guardas, por diminuto, pode manobrar, apenas, uma população prisional de cem presos, basta adotar o expediente de manter os internos trancados nos cubículos dia e noite, privados completamente de sol, para habilitar aquela quantidade de funcionários a custodiar mil e quinhentos. Se a verba de alimentação é suficiente para sustentar quinhentos internos, com duas refeições ao dia, pode-se destiná-la ao dobro, se se fornece uma única refeição diária. E assim por diante. ${ }^{66}$

Os números ratificam esse pensamento. A população carcerária do Brasil cresceu 83 vezes em 70 (setenta) anos ${ }^{67}$. O Brasil ocupa hoje o $4^{0}$ (quarto) lugar quando considerada a população prisional em termos absolutos ou relativos e possui a quinta maior taxa de ocupação dos estabelecimentos prisionais. ${ }^{68}$ De acordo com o Levantamento Nacional de Informações

${ }^{65}$ THOMPSON, Augusto. A questão penitenciária. $5^{\mathrm{a}}$ ed. Rio de Janeiro: Editora Forense, 2002. p. 101 ${ }^{66}$ Ibid. p. 102

${ }^{67}$ INSTITUTO DE PESQUISA ECONÔMICA APLICADA - Reincidência Criminal no Brasil. Relatório de Pesquisa. p. 10. Disponível em: <http://www.ipea.gov.br/portal/images/stories/PDFs/relatoriopesquisa/150611_relatorio_reinciden cia_criminal.pdf>. Acesso em: 25 ago. 2018.

${ }^{68}$ MINISTÉRIO DA JUSTIÇA/DEPARTAMENTO PENITENCIÁRIO NACIONAL - Modelo de gestão para política prisional. p. 21. Disponível em: < http://www.justica.gov.br/modelo-degestao_documento-final.pdf> . Acesso em: 15 set. 2018 
Penitenciarias, realizado pelo INFOPEN, em 2016, no Brasil, 726.712 mil pessoas estavam presas. Dessas, 689.510 em sistema penitenciário. Havia para todas, 368.049 vagas. Dessa forma, o déficit era de 358.663 mil vagas, redundando em uma taxa de ocupação de 197,4\% e em uma taxa de aprisionamento de $352,6{ }^{69}$. Em 2012, esse déficit era de 211.741 vagas $^{70}$, o que demonstra que os números só tendem a crescer.

Cabe observar, também, que de acordo com o estudo, há uma relação de 8,2 presos para cada agente no sistema prisional brasileiro. Esse número viola, de acordo com a pesquisa, a Resolução $n^{\circ} 9$ de 2009, do Conselho Nacional de Política Criminal e Penitenciaria (CNPCP), que indica a proporção de 1 agente para cada 5 pessoas presas como padrão razoável para garantia de segurança física e patrimonial das unidades prisionais, a partir do parâmetro oferecido pela Estatística Penal Anual do Conselho da Europa, data-base $2006 .^{71}$

Chama atenção a realidade do Estado do Amazonas, em que, de acordo com o estudo acima referido, detém a maior taxa de ocupação do país, aprisionando 48 pessoas em um espaço destinado a apenas 10 indivíduos $^{72}$ Concluindo a pesquisa em relação a superlotação carcerária, o relatório afirma que $52 \%$ da população prisional encontra-se em estabelecimentos penais que custodiam mais de 2 pessoas por vaga e apenas $7 \%$ da população (51.235 pessoas) encontram-se em unidades sem superlotação. ${ }^{73}$

\footnotetext{
${ }^{69}$ Ibid. p. 7.

${ }^{70}$ INSTITUTO DE PESQUISA ECONÔMICA APLICADA - Reincidência Criminal no Brasil. Relatório de Pesquisa. p. 10. Disponível em: <http://www.ipea.gov.br/portal/images/stories/PDFs/relatoriopesquisa/150611_relatorio_reinciden cia_criminal.pdf>. Acesso em: 25 ago. 2018.

${ }^{71}$ MINISTÉRIO DA JUSTIÇA/DEPARTAMENTO PENITENCIÁRIO NACIONAL - Modelo de gestão para política prisional. p. 48. Disponível em: < http://www.justica.gov.br/modelo-degestao_documento-final.pdf> . Acesso em: 15 set. 2018

${ }^{72}$ MINISTÉRIO DA JUSTIÇA/DEPARTAMENTO PENITENCIÁRIO NACIONAL - Modelo de gestão para política prisional. p. 26. Disponível em: < http://www.justica.gov.br/modelo-degestao_documento-final.pdf> . Acesso em: 15 set. 2018

${ }^{73}$ Ibid. p. 27
} 
O levantamento indica, ainda, que mantidas as taxas atuais de encarceramento, em oito anos será atingida a marca de um milhão de pessoas presas e em 2075 haverá uma pessoa privada de liberdade para cada grupo de dez habitantes. ${ }^{74}$

O excesso no número de presos impossibilita a eficácia de diversos direitos e políticas públicas, dificultando o processo de ressocialização. Se mesmo nas condições em que a Lei determina que as celas devem observar já é difícil se pensar em um ambiente digno para a existência humana, visto que ninguém se desenvolve em um ambiente tão pequeno, quiçá nas condições de hiperlotação que as penitenciárias brasileiras se encontram.

Aliás, um sistema penitenciário que conta com quase cinquenta mil presos, quando só poderia abrigar metade deles, que os amontoa sem nenhuma preocupação humanista ou ressocializadora, produzindo cenas diárias de horror e crueldade indescritíveis, que mantém em regime fechado mesmo os que foram benefícios com o regime semi-aberto, que não separa os condenados definitivos dos provisórios, que não permite, em muitos estabelecimentos penais, sequer a possibilidade de dormir em posição horizontal, etc., pode ser qualificado, para se dizer o mínimo, de caótico, desumano e cruel. ${ }^{75}$

A questão ora analisada impede que um dos princípios fundamentais da pena seja aplicado: o Princípio da Individualização da Pena, previstos nos $\operatorname{artigos} 5^{\circ}$ a $9^{\circ}$ da Lei de Execução Penal ${ }^{76}$, bem como na Constituição Federal

\footnotetext{
${ }^{74}$ Ibid. p. 28

${ }^{75}$ GOMES, Luiz Flávio. Penas e medidas alternativas à prisão. v. 1. São Paulo: Editora Revista dos Tribunais, 1999. p. 94.

76 Art. $5^{\circ}$ Os condenados serão classificados, segundo os seus antecedentes e personalidade, para orientar a individualização da execução penal.

Art. $6^{\circ}$ A classificação será feita por Comissão Técnica de Classificação que elaborará o programa individualizador da pena privativa de liberdade adequada ao condenado ou preso provisório.

Art. $7^{\circ}$ A Comissão Técnica de Classificação, existente em cada estabelecimento, será presidida pelo diretor e composta, no mínimo, por 2 (dois) chefes de serviço, 1 (um) psiquiatra, 1 (um) psicólogo e 1 (um) assistente social, quando se tratar de condenado à pena privativa de liberdade.

Parágrafo único. Nos demais casos a Comissão atuará junto ao Juízo da Execução e será integrada por fiscais do serviço social.

Art. $8^{\circ} \mathrm{O}$ condenado ao cumprimento de pena privativa de liberdade, em regime fechado, será submetido a exame criminológico para a obtenção dos elementos necessários a uma adequada classificação e com vistas à individualização da execução.

Parágrafo único. Ao exame de que trata este artigo poderá ser submetido o condenado ao cumprimento da pena privativa de liberdade em regime semi-aberto.
} 
no artigo art. $5^{\circ}$, inciso $\mathrm{XLVI}^{77}$. O excesso no número de presos impede que haja um controle e divisão de tipos de apenados por celas, o que gera uma dificuldade na diferença de tratamento entre eles, seja no que diz respeito a concessão de benefícios, seja no tratamento com maior senso de liberdade e auto responsabilidade, com maior permissibilidade ao detento.

É recomendável que todo estabelecimento possua divisões espaciais que estabeleçam diferentes graduações do nível de segurança, proporcionando tanto uma abordagem diferenciada nos níveis de contenção, como a progressão de cada pessoa privada de liberdade para os níveis mais brandos, de acordo com as avaliações que venham a ser realizadas por meio do Projeto Singular Integrado. ${ }^{78}$

Outro fato é que com esse hiperencarceramento o direito ao banho de sol diário, previsto pela LEP em seu artigo 52 inciso IV é privado. ${ }^{79}$ Isso porque a superlotação gera uma falta de espaço e devido à insuficiência de servidores em comparação com o número de presos, os guardas optam por não fornecer o banho de sol aos presos, uma vez que o pressuposto de seus trabalhos é a contenção das pessoas, necessitando se restringir o máximo qualquer tipo de movimentação suspeita pelos interiores dos ambientes prisionais.

Apesar das graves consequências oriundas dessa temática, o problema principal consiste em não existir um interesse efetivo em modificar esse hiperencarceramento, diminuindo as porcentagens analisadas. Isso porque o

77 Art. $5^{\circ}$ Todos são iguais perante a lei, sem distinção de qualquer natureza, garantindo-se aos brasileiros e aos estrangeiros residentes no País a inviolabilidade do direito à vida, à liberdade, à igualdade, à segurança e à propriedade, nos termos seguintes:

XLVI - a lei regulará a individualização da pena e adotará, entre outras, as seguintes:

a) privação ou restrição da liberdade;

b) perda de bens;

c) multa;

d) prestação social alternativa;

e) suspensão ou interdição de direitos;

${ }^{78}$ MINISTÉRIO DA JUSTIÇA/DEPARTAMENTO PENITENCIÁRIO NACIONAL - Modelo de gestão para política prisional. p. 264. Disponível em: < http://www.justica.gov.br/modelo-degestao_documento-final.pdf>. Acesso em: 15 set. 2018

79 Art. 52. A prática de fato previsto como crime doloso constitui falta grave e, quando ocasione subversão da ordem ou disciplina internas, sujeita o preso provisório, ou condenado, sem prejuízo da sanção penal, ao regime disciplinar diferenciado, com as seguintes características:

IV - o preso terá direito à saída da cela por 2 horas diárias para banho de sol. 
"amontoamento" de presos garante a submissão e o controle do caos, já que eles não circulam e consequentemente não interagem, fazendo soar para população como se o trabalho dos carcerários estivesse sendo bem feito, uma vez que esse visa o controle social, conforme demonstrado na primeira parte do presente trabalho.

É obvio, porém, que, pudessem os presos permanecer trancados o tempo todo, nos cubículos, ficaria reduzida a possibilidade de agressões e ataques de uns contra os outros. Porque isso lhes parece evidente, os guardas tendem a cortar, até o extremo máximo, as oportunidades de interação preso x preso. Daí desenvolverem um sistema informal de comandos, com o fito de reter os internos, o maior tempo possível, encarrados nos cubículos, ao mesmo passo em que, quando tal se mostra inviável, procurem limitar, asfixiantemente, seu campo de circulação. Providenciase, acaso tenha ela de ocorrer por necessidade extrema, fora da rotina, que o seja sob estrito controle e vigilância. ${ }^{80}$

A questão ora tratada é o alicerce de todas as lesões que o cumprimento da nossa Lei de Execuções Penais sofre. Essa afirmação decorre do fato de que, quando o espaço de circulação é mínimo, além de prejudicar fortemente a saúde física e psíquica humana, impossibilita as diversas outras formas de assistência de serem realizadas, uma vez que não existe equipe e suporte para todos os privados de sua liberdade.

\subsection{A questão educacional-laborativa}

\subsubsection{O direito à educação}

A LEP prega o direito do preso à uma assistência educacional, e não poderia ser diferente, uma vez que é direito inalienável do homem. Além disso, não se pode perder de vista que "o meio mais seguro, mas ao mesmo tempo mais difícil de tornar os homens menos inclinados a praticar o mal é aperfeiçoar a educação". ${ }^{81}$

\footnotetext{
${ }^{80}$ THOMPSON, Augusto. A questão penitenciária. $5^{\mathrm{a}}$ ed. Rio de Janeiro: Editora Forense, 2002. p. 60 .

${ }^{81}$ BECCARIA, Cesare. Dos delitos e das penas. 2a ed. São Paulo: Edipro, 2015. p. 109.
} 
O direito à educação é positivado nos artigos 17 a $21^{82}$. Dentre esses, o artigo 21 dispõe que o ensino deverá observar:

I - o nível de escolaridade dos presos e das presas;

II - a existência de cursos nos níveis fundamental e médio e o número de presos e presas atendidos;

III - a implementação de cursos profissionais em nível de iniciação ou aperfeiçoamento técnico e o número de presos e presas atendidos;

IV - a existência de bibliotecas e as condições de seu acervo;

$\mathrm{V}$ - outros dados relevantes para o aprimoramento educacional de presos e presas.

Cabe, nesse momento, um paralelo desse direito com o Princípio da Individualização da Pena, uma vez que o estudo e o aprimoramento capacitacional deverão ser feitos observando o nível de escolaridade e intelectualidade de cada preso, a fim de que seja prestado um serviço eficiente e que realmente incorpore seu patrimônio intelectual. Se feito dessa forma,

permite a desconstrução das logicas padronizadas e de homogeneização, que predominam no sistema prisional, compondo em última instancia os esforços para

${ }^{82}$ Art. 17. A assistência educacional compreenderá a instrução escolar e a formação profissional do preso e do internado.

Art. 18. O ensino de $1^{\circ}$ grau será obrigatório, integrando-se no sistema escolar da Unidade Federativa.

Art. 18-A. O ensino médio, regular ou supletivo, com formação geral ou educação profissional de nível médio, será implantado nos presídios, em obediência ao preceito constitucional de sua universalização. (Incluído pela Lei no 3.163, de 2015)

$\S 1$ o O ensino ministrado aos presos e presas integrar-se-á ao sistema estadual e municipal de ensino e será mantido, administrativa e financeiramente, com o apoio da União, não só com os recursos destinados à educação, mas pelo sistema estadual de justiça ou administração penitenciária. (Incluído pela Lei $\mathrm{n}^{\circ} 3.163$, de 2015)

$\S 20$ Os sistemas de ensino oferecerão aos presos e às presas cursos supletivos de educação de jovens e adultos. (Incluído pela Lei n ${ }^{\circ} 3.163$, de 2015)

§ 3o A União, os Estados, os Municípios e o Distrito Federal incluirão em seus programas de educação à distância e de utilização de novas tecnologias de ensino, o atendimento aos presos e às presas.

Art. 19. O ensino profissional será ministrado em nível de iniciação ou de aperfeiçoamento técnico. Parágrafo único. A mulher condenada terá ensino profissional adequado à sua condição.

Art. 20. As atividades educacionais podem ser objeto de convênio com entidades públicas ou particulares, que instalem escolas ou ofereçam cursos especializados. 
uma estratégia efetiva de singularização e de reconhecimento do protagonismo das pessoas privadas de liberdade. ${ }^{83}$

Caso contrário, será apenas uma educação feita mais para ganhar benefícios do que para realmente aprimorar o ser humano visando uma vida digna posterior às grades. $\mathrm{O}$ principal benefício é o criado com o advento da lei 13.433/2011, o instituto da remição, que diminui 1 dia de pena para cada 12 horas de frequência escolar: atividade de ensino fundamental, médio, inclusive profissionalizante ou superior, ou ainda de requalificação profissional, como afirma o artigo 126 parágrafo 1 o, inciso I. ${ }^{84}$

Ainda assim, de acordo com o INFOPEN, apenas $12 \%$ da população prisional no Brasil está envolvida em algum tipo de atividade educacional. Além disso, de acordo com o Plano Estratégico de Educação em Prisões, “47\% dos estabelecimentos sequer possuem qualquer espaço para oferta de atividades escolares." 85

Não obstante os $53 \%$ dos estabelecimentos que contam com espaço destinado à educação, o Brasil apresenta uma média histórica de atendimento escolar que gira em torno de $10 \%$ a $12 \%$ de alunos dentre o total de pessoas privadas de liberdade, o que demonstra que mesmo nos casos em que há local para atendimento escolar esse não é eficiente ou não é feito. ${ }^{86}$

De acordo com o Relatório de Reincidência realizado pelo IPEA, nas penitenciárias visitadas os sem instrução ou com ensino fundamental perfazem $75,1 \%$ do total, proporção que é ainda mais contundente entre os

\footnotetext{
${ }^{83}$ MINISTÉRIO DA JUSTIÇA/DEPARTAMENTO PENITENCIÁRIO NACIONAL - Modelo de gestão para política prisional. p. 42. Disponível em: < http://www.justica.gov.br/modelo-degestao_documento-final.pdf> . Acesso em: 15 set. 2018

${ }^{84}$ Art. 126 . O condenado que cumpre a pena em regime fechado ou semiaberto poderá remir, por trabalho ou por estudo, parte do tempo de execução da pena. (Redação dada pela Lei ${ }^{\circ} 12.433$, de 2011).

$\S 1$ o A contagem de tempo referida no caput será feita à razão de: (Redação dada pela Lei $n^{\circ} 12.433$, de 2011)

II - 1 (um) dia de pena a cada 3 (três) dias de trabalho. (Incluído pela Lei no ${ }^{\circ} 12.433$, de 2011)

${ }^{85}$ MINISTÉRIO DA JUSTIÇA/DEPARTAMENTO PENITENCIÁRIO NACIONAL - Modelo de gestão para política prisional. p. 120. Disponível em: < http://www.justica.gov.br/modelo-degestao_documento-final.pdf $>$. Acesso em: 15 set. 2018

${ }^{86}$ Ibidem. p. 121-122
} 
reincidentes, nos quais $80,3 \%$ da amostra encontram-se nessa categoria. Os que possuem ensino fundamental completo ou médio incompleto perfazem 14,4\%. Apenas $8,5 \%$ dos apenados tem ensino médio completo ou superior incompleto. Os com ensino superior completo são apenas 1,9\% entre os apenados, e 0,7\% entre os reincidentes (apenas um caso). ${ }^{87}$

Esses números demonstram, portanto, como a falta de educação escolar e o cometimento de crimes estão conectados, principalmente nos casos em que as pessoas voltam a delinquir. Por esse motivo, deve-se, a todo tempo, tentar possibilitar a eficácia da prestação educacional dentro das penitenciárias, fator que transforma o ser humano e pode, inclusive, o afastar da criminalidade.

\subsubsection{O direito ao trabalho}

"O trabalho assume, nas prisões, um papel central para a configuração das dinâmicas de convívio, de ocupação, de obtenção de renda e de representação simbólica acerca das motivações e intencionalidades das pessoas em privação de liberdade para a construção de sua trajetória de preparação para a liberdade." 88

A LEP afirma a obrigatoriedade ao trabalho em seu artigo 31, expondo, logo após, que deverão ser observadas as habilitações e condições pessoais do privado de liberdade. ${ }^{89}$ Assim como na área educacional, para se desenvolver serviços laborativos deve-se atentar para as condições pessoais do agente, na medida de seu conhecimento prévio.

\footnotetext{
${ }^{87}$ INSTITUTO DE PESQUISA ECONÔMICA APLICADA - Reincidência Criminal no Brasil. Relatório de Pesquisa. p. 25. Disponível em: <http://www.ipea.gov.br/portal/images/stories/PDFs/relatoriopesquisa/150611_relatorio_reinciden cia_criminal.pdf $>$. Acesso em: 25 ago. 2018.

${ }^{88}$ MINISTÉRIO DA JUSTIÇA/DEPARTAMENTO PENITENCIÁRIO NACIONAL - Modelo de gestão para política prisional. p. 315. Disponível em: < http://www.justica.gov.br/modelo-degestao_documento-final.pdf> . Acesso em: 15 set. 2018

89 Art. 31. O condenado à pena privativa de liberdade está obrigado ao trabalho na medida de suas aptidões e capacidade.

Parágrafo único. Para o preso provisório, o trabalho não é obrigatório e só poderá ser executado no interior do estabelecimento.
} 
A realidade brasileira, porém, destoa fortemente desse cenário, seja por não haver possibilidade de todos os presos obterem trabalho (interno ou externo), devido à superlotação, seja por, quando esse trabalho for possível, não serem observadas as condições pessoais do preso, se tornando apenas mais um mecanismo para obter benefícios como remição e taxativa de bom comportamento carcerário (visando um livramento condicional).

De acordo com o INFOPEN, em 75\% das prisões não existem espaços destinados ao exercício de atividade laborativa. ${ }^{90}$ Em junho de 2016, $15 \%$ da população prisional estava envolvida em atividades laborais, internas e externas aos estabelecimentos penais, o que representa um total de 95.919 pessoas. Analisando a realidade do Estado do Rio de Janeiro, por exemplo, temos que dos 51.787 presos do estado, apenas $4 \%$ trabalham. ${ }^{91}$

A LEP prevê ainda, que o trabalho da pessoa privada de liberdade deverá ser remunerado e esse valor não poderá ser inferior a 3/4 do salário mínimo. ${ }^{92}$ Em 2016, esse limite representava 660 reais. Apesar disso, 75\% da população prisional em atividade laboral não ganhava remuneração ou recebia menos que $3 / 4$ do determinado pela lei. ${ }^{93}$

O salário do trabalhador penal não retribui uma produção; funciona como motor e marca transformações individuais: uma ficção jurídica, pois não representa a "livre" cessão de uma força de trabalho, mas um artificio que se supõe eficaz nas técnicas de correção. ${ }^{94}$

\footnotetext{
${ }^{90}$ MINISTÉRIO DA JUSTIÇA/DEPARTAMENTO PENITENCIÁRIO NACIONAL - Modelo de gestão para política prisional. p. 145. Disponível em: < http://www.justica.gov.br/modelo-degestao_documento-final.pdf $>$. Acesso em: 15 set. 2018

${ }^{91}$ BOTTARI, Elenilce. No Rio, apenas $4 \%$ dos presos cumprem lei que estabelece que detentos trabalhem. Jornal O Globo, 08/08/2018 - 04:30. Disponível em: <https://oglobo.globo.com/rio/norio-apenas-4-dos-presos-cumprem-lei-que-estabelece-que-detentos-trabalhem22958747\#ixzz5Nb086BMx stest>. Acesso em: 2 out. 2018.

92 Art. 29. O trabalho do preso será remunerado, mediante prévia tabela, não podendo ser inferior a 3/4 (três quartos) do salário mínimo.

${ }^{93}$ MINISTÉRIO DA JUSTIÇA/DEPARTAMENTO PENITENCIÁRIO NACIONAL - Modelo de gestão para política prisional. p. 58. Disponível em: < http://www.justica.gov.br/modelo-degestao_documento-final.pdf>. Acesso em: 15 set. 2018

${ }^{94}$ FOUCAULT, Michel. Vigiar e Punir: nascimento da prisão. $42^{\mathrm{a}}$ ed. Rio de Janeiro: Editora Vozes, 2018. p. 236.
} 
A Lei dispõe também, em relação ao trabalho, sobre o instituto da remição. Assim, o preso recebe o desconto de um dia na pena a cada três dias trabalhados.

Mesmo nos casos em que os presos efetivamente prestam atividades laborativas, $87 \%$ são atividades internas ao estabelecimento, o que na maior parte das vezes não condiz com o regime que o preso se encontra e nem com seu comportamento carcerário, que já permitiriam um trabalho externo e consequentemente um maior contato com a sociedade, almejando uma reinserção. ${ }^{95}$ Ademais, os serviços prestados dentro da penitenciária muitas vezes não estão adequados ao nível de capacitação do privado de liberdade, deixando de funcionar como um método de tratamento, de sentimento de responsabilidade e de superação pessoal, para permanecer como método de benefícios de cumprimento de pena, como acima afirmado.

É importante que as demais atividades sejam oferecidas de acordo com o níveis de interesse e habilidade dos sujeitos, de modo que possam compor um portfólio de formação integrada, com vistas a preparar todos para o retorno a liberdade civil. 96

Como se percebe, trata-se de um "cenário de omissão e ilegalidade estatal, sendo vedado às pessoas privadas de liberdade, ao mesmo tempo, o gozo de seu direito e o cumprimento de seu dever." 97 Fora isso, perde-se de vista um importante fator na tentativa de se fazer perceber no preso um sentimento de responsabilidade, importante para seu retorno ao convivo social. Nesse mesmo sentido,

O trabalho prisional, que atualmente tem recebido contundentes críticas dos especialistas europeus, notadamente dos espanhóis, tem destacada importância no sistema brasileiro e é considerado como um dos fatores mais importantes na tarefa ressocializadora do delinquente", com elevada função pedagógica. ${ }^{98}$

\footnotetext{
${ }^{95}$ MINISTÉRIO DA JUSTIÇA/DEPARTAMENTO PENITENCIÁRIO NACIONAL - Modelo de gestão para política prisional. p. 57. Disponível em: < http://www.justica.gov.br/modelo-degestao_documento-final.pdf> . Acesso em: 15 set. 2018

${ }^{96}$ Ibid. p. 41.

${ }^{97}$ Ibid. p. 146.

${ }^{98}$ BITENCOURT, Cezar Roberto. Falência da pena de Prisão: Causas e Alternativas. $5^{\mathrm{a}}$ ed. São Paulo: Saraiva, 2017. p. 437.
} 
O trabalho penal não pode ser criticado pelo desemprego que provocaria: com sua parca extensão, seu fraco rendimento, ele não pode ter incidência geral sobre a economia. Não é como atividade de produção que ele é intrinsecamente útil, mas pelos efeitos que toma na mecânica humana. É um princípio de ordem e de regularidade; pelas exigências que lhe são próprias, veicula, de maneira insensível, as formas de um poder rigoroso; sujeita os corpos a movimentos regulares, exclui a agitação e a distração, impõe uma hierárquica e uma vigilância que serão ainda mais bem-aceitas, e penetrarão ainda mais profundamente no comportamento dos condenados, por fazerem parte de sua lógica. ${ }^{99}$

O direito ao trabalho é a assistência mais importante que a LEP pode fornecer a um privado de liberdade. Isso porque com o trabalho, além de conseguir diminuir seu tempo de pena através da remissão, o apenado consegue obter salário (ainda que pequeno), e enviá-lo a sua família para sustentá-lo. Para muitos, isso é sinônimo de não ter perdido sua "razão", e o que os mantém esperançosos de voltar a liberdade e não delinquir.

Na percepção dos entrevistados, ter um emprego, além de importante para a subsistência, também produzia elevação moral e da autoestima, o que consideravam fundamental para o bom convívio social. ${ }^{100}$

\subsection{A assistência social e à saúde}

O artigo 14 da LEP prevê o direito à saúde, bem como a nossa Constituição Federal, do artigo 196 e 197. ${ }^{101}$ No ambiente prisional, esse direito deve ser atentado de forma especial, pelo simples motivo de ser um espaço de confinamento. Ainda mais na realidade brasileira de hiperencarceramento, em que as celas não contam com as condições mínimas

\footnotetext{
${ }^{99}$ FOUCAULT, Michel. Vigiar e Punir: nascimento da prisão. $42^{\mathrm{a}}$ ed. Rio de Janeiro: Editora Vozes, 2018. p. 235.

${ }^{100}$ INSTITUTO DE PESQUISA ECONÔMICA APLICADA - Reincidência Criminal no Brasil. Relatório de Pesquisa. p. 45. Disponível em: <http://www.ipea.gov.br/portal/images/stories/PDFs/relatoriopesquisa/150611_relatorio_reinciden cia_criminal.pdf $>$. Acesso em: 25 ago. 2018.

${ }^{101}$ Art. 14. A assistência à saúde do preso e do internado de caráter preventivo e curativo, compreenderá atendimento médico, farmacêutico e odontológico.

Art. 196. A saúde é direito de todos e dever do Estado, garantido mediante políticas sociais e econômicas que visem à redução do risco de doença e de outros agravos e ao acesso universal e igualitário às ações e serviços para sua promoção, proteção e recuperação.

Art. 197. São de relevância pública as ações e serviços de saúde, cabendo ao Poder Público dispor, nos termos da lei, sobre sua regulamentação, fiscalização e controle, devendo sua execução ser feita diretamente ou através de terceiros e, também, por pessoa física ou jurídica de direito privado.
} 
de iluminação, higiene e ventilação, “os estabelecimentos prisionais são ambientes propícios para a propagação de diversas doenças, além de serem espaços produtores de transtornos psíquicos e mentais." 102

O direito à saúde pode ser analisado, basicamente, sobre três vertentes: o viés de continuação de tratamento, de prevenção e de assistência emergencial, abrangendo, em todos esses, o âmbito não só da saúde física, mas também da mental.

As equipes de saúde devem realizar processos periódicos de busca ativa de agravos nos pavilhões habitacionais e celas. Para tanto, são fundamentais o planejamento e a execução de ações coordenadas entre equipes básicas de saúde e o núcleo de rotinas e horários, envolvendo ainda a Vigilância Sanitária e Vigilância Epidemiológica. Tais ações de busca ativa devem propiciar: 1. vistoriar todas as instalações e áreas do estabelecimento prisional, verificando e corrigindo as situações favorecedoras de contágio e propagação de doenças; 2. identificar os casos positivos de ocorrência de HIV/Aids, Tuberculose, Hipertensão, Diabetes, Hepatites e Hanseníase, realizando o tratamento de todas as pessoas positivadas; 3. criar áreas livres de contágio, contribuindo para a produção de ambientes seguros e humanitários no interior dos estabelecimentos prisionais. ${ }^{103}$

Os próximos números ratificam a necessidade desse direito ser prestado de forma eficiente. O Modelo de Gestão assinala que o informe Mundial sobre os Direitos Humanos - Edição 2015, apresentado por Human Rights Watch, destaca que a incidência de HIV nas prisões é 60 vezes maior que no restante da população.

Por esse motivo, é importante observar a Resolução 09, de 13 de Novembro de 2009 do Conselho Nacional de Política Criminal e Penitenciária (CNPCP), que em seu artigo $2^{\circ}$ estabelece uma relação entre uma proporção de profissionais para 500 (quinhentos) detentos. Nesse ponto, cabe atentar para os seguintes números:

- Médico Clínico - 1

\footnotetext{
${ }^{102}$ MINISTÉRIO DA JUSTIÇA/DEPARTAMENTO PENITENCIÁRIO NACIONAL - Modelo de gestão para política prisional. p. 95. Disponível em: < http://www.justica.gov.br/modelo-degestao_documento-final.pdf> . Acesso em: 15 set. 2018

${ }^{103}$ MINISTÉRIO DA JUSTIÇA/DEPARTAMENTO PENITENCIÁRIO NACIONAL - Modelo de gestão para política prisional. p. 342. Disponível em: < http://www.justica.gov.br/modelo-degestao_documento-final.pdf $>$. Acesso em: 15 set. 2018
} 
- Enfermeiro - 1

- Auxiliar de enfermagem - 1

- Odontológo - 1

- Auxiliar de consultório dentário - 1

- Nutricionista -1

Como já pontuado no relatório da INFOPEN, todas as categorias ligadas a saúde representam $6 \%$ dos servidores do sistema penal, demonstrando mais uma vez a desproporção entre o pessoal da assistência e o número de presos. O problema é que na prática, em razão da quantidade de presos a serem tratados e da impossibilidade de locomoção constante dentro da penitenciária, o direito à saúde não chega a todos com facilidade.

O direito à saúde muitas vezes é negligenciado e, em geral, encontra-se submetido a procedimentos de contenção, de modo que a chegada das pessoas privadas de liberdade aos setores de saúde é precedida de uma triagem informal realizada pelos agentes de segurança. ${ }^{104}$

Um ponto que merece ressalva é que no Modelo de Gestão, utilizado como fonte da presente pesquisa, não se encontram dados sobre a saúde dos detentos, diferente das outras assistências analisadas, que por mais que os números sejam da mesma forma chocantes, existem diversas pesquisas e taxas, como já apresentadas.

A assistência social está prevista nos artigos 22, 23 e 40 da LEP. Sendo seu objetivo principal "amparar o preso e o internado e prepará-los para o retorno à liberdade."105 É por isso que se pode dizer que o serviço social "é o

\footnotetext{
${ }^{104}$ MINISTÉRIO DA JUSTIÇA/DEPARTAMENTO PENITENCIÁRIO NACIONAL - Modelo de gestão para política prisional. p. 114. Disponível em: < http://www.justica.gov.br/modelo-degestao_documento-final.pdf $>$. Acesso em: 15 set. 2018

${ }^{105}$ Art. 22. A assistência social tem por finalidade amparar o preso e o internado e prepará-los para o retorno à liberdade.

Art. 23. Incumbe ao serviço de assistência social:

I - conhecer os resultados dos diagnósticos ou exames;

II - relatar, por escrito, ao Diretor do estabelecimento, os problemas e as dificuldades enfrentadas pelo assistido;

III - acompanhar o resultado das permissões de saídas e das saídas temporárias;

IV - promover, no estabelecimento, pelos meios disponíveis, a recreação;
} 
campo de integração de todas as políticas prisionais"106, uma vez que todas essas visam, sobretudo, fornecerem condições dignas ao preso no período de cumprimento de pena para que, quando retornar à vida livre, esteja apto a esta de forma adequada.

Apesar da sua importância no plano teórico, na prática merece ainda mais atenção. De acordo com a mesma Resolução 09, de 13 de Novembro de 2009, deveriam haver, para 500 presos:

- Psicólogo - 1

- Estagiário de psicologia -6

- Assistente social - 1

- Estagiário de assistente social - 6

- Terapeuta ocupacional - 1

Mas, na realidade, de acordo com o Modelo de Gestão, tem-se uma proporção de 1,01 profissional para cada estabelecimento, numa escala de 01 profissional para cada grupo aproximado de 401 pessoas privadas de liberdade. A conclusão que essa pesquisa chegou é que o dado "indicar haver uma proporção até melhor do que aquilo que está estabelecido pelo Conselho Nacional de Política Criminal e Penitenciária." 107

Analisa, contudo, que esse resultado positivo não está em consonância com a realidade vivenciada nos estabelecimentos, e o número é formado muito por conta de alguns estados terem uma boa taxa, como por exemplo

\footnotetext{
V - promover a orientação do assistido, na fase final do cumprimento da pena, e do liberando, de modo a facilitar o seu retorno à liberdade;

VI - providenciar a obtenção de documentos, dos benefícios da Previdência Social e do seguro por acidente no trabalho; VII - orientar e amparar, quando necessário, a família do preso, do internado e da vítima. Art. 40 - Impõe-se a todas as autoridades o respeito à integridade física e moral dos condenados e dos presos provisórios.

${ }^{106}$ MINISTÉRIO DA JUSTIÇA/DEPARTAMENTO PENITENCIÁRIO NACIONAL - Modelo de gestão para política prisional. p. 90. Disponível em: < http://www.justica.gov.br/modelo-degestao_documento-final.pdf>. Acesso em: 15 set. 2018 ${ }^{107}$ MINISTÉRIO DA JUSTIÇA/DEPARTAMENTO PENITENCIÁRIO NACIONAL - Modelo de gestão para política prisional. p. 134. Disponível em: < http://www.justica.gov.br/modelo-degestao_documento-final.pdf > . Acesso em: 15 set. 2018
} 
Bahia, Acre e São Paulo, que contam com mais de dois profissionais para cada estabelecimento. Na maioria dos outros, porém, tem-se dados como 4 profissionais para 32 estabelecimentos, como no Rio Grande do Norte, 23×159 no Ceará e 22×100 em Goiás. ${ }^{108}$

Além disso, mesmo nos estabelecimentos prisionais em que existem profissionais dentro da média exigida, a ausência de sala para atendimento específico do serviço social abrange cerca de $70 \%$ desses. ${ }^{109}$ Não obstante, esses, em sua maioria, "sequer possuem espaços adequados para receber as visitas sociais e íntimas, de modo que também esta atribuição do serviço social penitenciário fica prejudicada, questão que será analisada em momento próprio." 110

É importante ter em mente que a assistência social é um direito, não podendo ser utilizado como forma de se conceder regalias ou privilégios para um certo número de presos com características específicas. Todos têm direito a se comunicar com suas famílias e amigos, como forma de interação com o mundo exterior.

De acordo com o Relatório de Reincidência, analisando as entrevistas com os profissionais da assistência social de algumas penitenciárias brasileiras, esses relataram que

notava-se uma grande diferença entre os presos que tinham uma proximidade com a família e os que haviam sido por ela abandonados, estes considerados indivíduos menos propícios à reintegração social. Por isso tentavam trazer a família para perto dos internos. ${ }^{111}$

Relativamente a esse contato familiar, uma questão importante é a sexualidade. Ela deve ser analisada por ser de natureza instintiva do ser humano, que não cessa ao adentrarem os muros da penitenciária. Podemos

\footnotetext{
${ }^{108}$ Ibid. p. 134.

${ }^{109}$ Ibid. p. 135

${ }^{110}$ Ibid. p. 137

${ }^{111}$ INSTITUTO DE PESQUISA ECONÔMICA APLICADA - Reincidência Criminal no Brasil.

Relatório de Pesquisa. p. 35. Disponível em:

<http://www.ipea.gov.br/portal/images/stories/PDFs/relatoriopesquisa/150611_relatorio_reinciden cia_criminal.pdf $>$. Acesso em: 25 ago. 2018.
} 
perceber quatro problemas decorrentes da privação da sexualidade: a quebra de relações com seus companheiros(as), a saúde mental do preso e a homossexualidade decorrente das violências dentro da penitenciária e/ou a necessidade de autoerotismo.

Em decorrência da privação de liberdade, o número de divórcios é maior na prisão do que vida fora dos muros (ver aonde encontrei). Não bastasse as diversas mudanças físicas e psicológicas vivenciadas de forma abrupta pelo preso, a desvinculação a pessoa que era retrato de sua vida exterior e de seu passado acarreta sérios problemas, além de ser uma clara violação ao princípio da personalidade da pena, previsto na Constituição do artigo XLV, "visto que, quando se priva o recluso de suas relações sexuais normais, castiga-se também o cônjuge inocente" 112

Reduzidos os contatos sexuais com seus parceiros, ou até mesmo as relações amorosas que tinham com elas, aos privados de liberdade sobra o autoerotismo, ou, em algumas vezes, a homossexualidade, sendo importante dizer que muitas vezes essa é forçada, nas famosas "curras penitenciárias". Com tudo isso, o preso é afastado do seu papel de "homem" na sociedade, da constituição de um núcleo familiar e da sua "masculinidade", traços que levam à uma degradação moral que o torna cada vez mais distante da sua reinserção à sociedade.

\section{5) Lei $x$ Realidade: como atuar?}

Como se demonstrou ao longo do capítulo, apesar da LEP contar com um corpo repleto de direitos ao preso, os números alertam que poucos são realmente aplicados na prática e, quando são, muitas vezes não atingem o nível desejado e que possibilite um tratamento individual ao preso visando o

\footnotetext{
112 BITENCOURT, Cezar Roberto. Falência da pena de Prisão: Causas e Alternativas. $5^{\mathrm{a}}$ ed. São
} Paulo: Saraiva, 2017. p. 234. 
retorno sociedade. Na maioria das vezes, se tornam apenas instrumentos para os presos conseguirem benefícios legais, como o da remição, e um tratamento "para inglês ver".

É importante que se perceba que muitas das impossibilidades da eficácia nas assistências avaliadas decorrem da disfuncionalidade entre a hiperlotação e o número do pessoal de tratamento no âmbito de suas funções. A impossibilidade de se tratar um preso, como previsto na LEP, querendo também o punir e retribuindo o mal causado pelo crime, é evidente. A desproporcionalidade entre o pessoal de contenção frente aos de assistência é o ponto de partida para todas as violações que foram analisadas.

Por esse motivo, deve-se pensar em alternativas para esse sistema penal que pouco cumpre o que legalmente garante, sendo essa omissão impulsionada pelo pensamento social vigente, mas também por falta de capacitação de seus agentes e por falta de pessoal.

Passa-se, nesse momento, a fazer uma análise do que acontece com o preso depois de sair da penitenciária, adentrando a última das assistências, a assistência ao egresso, e os motivos pelos esses são levados a reincidirem. Analisa-se, em um segundo momento, as soluções que foram criadas para desafogar o sistema carcerário e possibilitar um cumprimento de pena junto a sociedade, visando mudar esse pensamento social e deixar nas penitenciárias apenas os condenados por crimes mais graves, possibilitando que a esses, em um ambiente menos hiperlotado, seja prestado um serviço assistencial coerente com as normativas legais. 


\section{Capítulo III - A assistência ao egresso e a reincidência analisadas frente ao fracasso da Pena Privativa de Liberdade e o papel das penas e medidas alternativas no cenário atual.}

\subsection{A assistência ao egresso e a reincidência criminal brasileira}

A assistência ao egresso é a última assistência, sendo fundamental para que todos os serviços que, em tese, foram prestados durante o cumprimento da pena privativa de liberdade sejam postos em prática e ajudem o liberto a não reincidir. Com trabalho e renda mensal, por ter estado em contato com educação e trabalhos de reintegração no período prisional, o preso não submergirá à criminalidade novamente.

$\mathrm{O}$ artigo 25 da LEP prevê a assistência ao egresso. ${ }^{113} \mathrm{Na}$ teoria, deveriam ser proporcionadas, apoio psicológico e material ao liberto. Porém, de acordo com o Relatório de Reincidência, elaborado pelo IPEA,

Nos casos pesquisados, praticamente inexistiam ações voltadas ao egresso do sistema prisional. O único programa que se teve conhecimento nas experiências visitadas tinha enormes limitações no plano de estrutura humana e material. Nesse sentido, os estudos de casos apontaram para a necessidade de desenvolvimento e investimentos em ações e programas voltados para o público egresso, reconhecendo o seu papel relevante na promoção da reintegração social. ${ }^{114}$

O Relatório de pesquisa Reincidência Criminal no Brasil baseia-se no conceito de reincidência legal, "aplicável apenas aos casos em que há condenações de um indivíduo entre o cumprimento de pena e a determinação

\footnotetext{
113 Art. 25. A assistência ao egresso consiste:

I - na orientação e apoio para reintegrá-lo à vida em liberdade;

II - na concessão, se necessário, de alojamento e alimentação, em estabelecimento adequado, pelo prazo de 2 (dois) meses.

Parágrafo único. O prazo estabelecido no inciso II poderá ser prorrogado uma única vez, comprovado, por declaração do assistente social, o empenho na obtenção de emprego.

${ }^{114}$ INSTITUTO DE PESQUISA ECONÔMICA APLICADA - Reincidência Criminal no Brasil.

Relatório de Pesquisa. p. 116. Disponível em:

<http://www.ipea.gov.br/portal/images/stories/PDFs/relatoriopesquisa/150611_relatorio_reinciden cia_criminal.pdf $>$. Acesso em: 25 ago. 2018.
} 
de uma nova sentença inferior num período inferior a cinco anos." 115 Ou seja, analisa os reincidentes de acordo com o conceito de reincidência previsto no artigo 63 do Código Penal. Nessa pesquisa, analisados estabelecimentos penais em torno do Brasil, a média ponderada foi de 24,4\%. "Concluiu-se que, a cada quatro apenados, um é reincidente legalmente." 116

É importante considerar que em razão da delimitação do conceito de reincidência, os números obtidos por essa pesquisa são inferiores ao normalmente atribuídos à reincidência criminal no Brasil, que giram em torno de 70 a $80 \% .{ }^{117}$ O DEPEN, por exemplo, utiliza como indicador de número de reincidência o número de presos recolhidos no ano com passagem anterior pelo sistema (condenados ou não). De acordo com o IPEA, portanto, a porcentagem de $70 \%$ está sobrestimada, uma vez que insere os presos provisórios, que não necessariamente são condenados.

Enfim, apesar dos números variarem quando se mudam os critérios de reincidência analisados, em todos os casos os números são elevados, girando em torno de $30 \%$, o que demonstra, mais uma vez, a ineficácia da prisão como método de reintegração social. ${ }^{118}$

O quadro de reincidência é ruim, mas o resultado não é chocante. De uma penitenciária que produz injustiças e não consagra os direitos legalmente previstos pelo Estado aos que estão sob sua custódia, não poderia se espera diferente. Como se demonstrou, das diversas assistências previstas pela LEP, a maioria não é aplicada na prática, e, quando são, na maioria das vezes não são para todos e são feitas de forma precárias.

Entrevistando presos e agentes do sistema penitenciário, a pesquisa apontou pontos principais relatados por esses ao se tratar do motivo pelo qual

\footnotetext{
${ }^{115}$ INSTITUTO DE PESQUISA ECONÔMICA APLICADA - Reincidência Criminal no Brasil. Relatório de Pesquisa. p. 23. Disponível em: <http://www.ipea.gov.br/portal/images/stories/PDFs/relatoriopesquisa/150611_relatorio_reinciden cia_criminal.pdf $>$. Acesso em: 25 ago. 2018

116 Ibid. p. 111.

117 Ibid. p. 11

118 Ibid. p. 12
} 
os presos reincidiriam. Os mais citados foram o abandono da família, a dificuldade de se encontrar emprego e as péssimas condições das penitenciárias. De acordo com eles, muitas vezes, a família do egresso não o acolhia, o que seria, na opinião desses grupos, fundamental para prevenir a reincidência. O segundo motivo seria a dificuldade de inserção no mercado de trabalho, havendo crítica à falta de políticas voltadas a esse problema. Observou-se que, ainda nos casos em que havia oportunidade de emprego a baixa qualificação da população egressa fazia com que os salários fossem baixos, o que muitas vezes faziam-nos cair na tentação do crime, por ser mais rentável. ${ }^{119}$

Afirmavam que a reincidência dependia também, em parte, da efetivação ou não das assistências determinadas pela LEP, bem como projetos de acompanhamento para o público egresso.

Aliada à falta de orientação da pena de prisão para propostos ressocializadores estava a falta de oportunidades oferecidas aos internos. Em linhas gerais, a percepção dos entrevistados era de que a maioria dos internos não tinha intenção de voltar ao crime. Entretanto, isto acabava acontecendo por falta de políticas de inclusão voltadas para o egresso, aliada à não aceitação do ex-detento pela sociedade, dificultando sua reintegração por meio do trabalho lícito. ${ }^{120}$

É interessante analisar também que com a realidade cruel, que muitas vezes chega a condições análogas a tortura, o processo de arrependimento, de análise dos atos que cometeram fica dificultado, uma vez que os presos se veem em uma situação horrível, submetidos a um regime tirânico e sem poder expressar sua insatisfação. Dessa forma, passa a se ver como vítima, por em seu consciente estar recebendo uma punição muito maior do que o mal causado.

Como a ciência da vitimologia vem apontando que aquele que se vê como vítima, ao não elaborar seus sentimentos, suas dúvidas, suas necessidades, passa a ter uma probabilidade alta de voltar a agir de modo violento. Em verdade, "não resolve e

\footnotetext{
${ }^{119}$ INSTITUTO DE PESQUISA ECONÔMICA APLICADA - Reincidência Criminal no Brasil. Relatório de Pesquisa. p. 96. Disponível em: <http://www.ipea.gov.br/portal/images/stories/PDFs/relatoriopesquisa/150611_relatorio_reinciden cia_criminal.pdf>. Acesso em: 25 ago. 2018 ${ }^{120}$ Ibid. p. 99
} 
não transforma e não leva a qualquer responsabilização; ao contrário, em busca de um culpado para punir, acaba por retroalimentar o ciclo de violência a médio e longo prazo." 121

Outro grande problema apontado foi o já analisado no presente estudo: o hiperencarceramento acaba por proporcionar a não diferenciação dos presos pelo delito cometido.

Apenas o condenado por crime de natureza sexual ou beneficiado pela delação premiada estava inserido em pavilhão diferenciado, não em decorrência da natureza do crime, mas sim para a proteção de sua integridade física. ${ }^{122}$

Isso é um grande motivo para que a prisão se torne um ambiente para a criminalidade, já que a não separação das celas por delitos gera a interação de pessoas que não cometeram crimes violentos com pessoas que cometeram crimes violentos, que muitas vezes são inseridos em organizações criminosas, e, com medo de ser violentado ou sofrer injustiças, não resta ao preso se unir ao grupo, aprisionando-se e "saindo pior do que entrou".

Como se percebe, diante de todas as impossibilidades do preso de ter seu direito a um cumprimento de pena digno, pela dificuldade em se prestar todos os serviços assistenciais acima referidos, e, baseados no quadro de reincidência supramencionado, podemos observar que a função ressocializadora da pena muitas vezes não é atingida. Pelo contrário, nas condições em que se encontram, as penitenciárias propiciam uma constante degradação humana, com práticas que se assemelham a tortura e um ambiente que se considera um ambiente que aumenta as tendências criminosas.

É preciso reconhecer que o aprisionamento de enorme contingente de pessoas não representa o sucesso da política de segurança pública - pelo contrário, agrava a

\footnotetext{
${ }^{121}$ ALMEIDA, Tânia; PELAJO, Samantha; JONATHAN, Eva (Coord.). Mediação de Conflitos: para iniciantes, praticantes e docentes. $1^{\text {a }}$ ed. Salvador: Editora JusPodivm, 2016. p. 671 apud TAVARES, Luisa de Araujo. Efeitos de Prisionização: A ineficácia da prisão como sanção penal. $1^{\text {a }}$ ed. Rio de Janeiro: Editora Palma, 2018. p. 62.

${ }^{122}$ INSTITUTO DE PESQUISA ECONÔMICA APLICADA - Reincidência Criminal no Brasil.

Relatório de Pesquisa. p. 48. Disponível em:

$<\mathrm{http} / / /$ www.ipea.gov.br/portal/images/stories/PDFs/relatoriopesquisa/150611_relatorio_reinciden cia_criminal.pdf $>$. Acesso em: 25 ago. 2018
} 
situação da violência, profissionalizando no crime aqueles que, supostamente, se pretende recuperar.

[...]

Faz-se, urgente, portanto, assumir uma proposta de desencarceramento, entendendo este processo tanto no sentido de diminuir o número de pessoas condenadas à prisão, como no sentido de promover ações que beneficiam a progressão de pena e a celeridade nos julgamentos de direitos processuais. ${ }^{123}$

\subsection{As penas e medidas alternativas como desafogamento do sistema carcerário e tentativa de interação com a sociedade}

Visando isso, uma das soluções criadas com o fito de reduzir a população carcerária brasileira foram os chamados mecanismos despenalizadores. Dentre eles, merece destaque as Penas e Medidas Alternativas, introduzidas ao nosso ordenamento jurídico através da lei 9714/1998, que modificou o nosso Código Penal.

A falência ou o fracasso da pena de prisão, é, por isso mesmo, o fator preponderante para a difusão das penas e das medidas alternativas que, no princípio, começaram pretendendo exclusivamente o encurtamento de sua duração (livramento condicional, remição, etc) ou evitar a sua execução (sursis, penas substitutivas, etc), impedindo, desse modo, seus efeitos deletérios (contato pernicioso, estigmatização, "prisonizaçao", etc), para depois apresentarem-se como verdadeiras alternativas, isto é, como penas autônomas e distintas, que contam com a pretensão de ocupar o lugar da prisão (em razão da sua desproporcionalidade, desumanidade, crueldade etc).

[...]

Os defensores das penas e medidas alternativas sustentam que seus maiores virtudes residiriam no seguinte: a) evitar o encarceramento, e, em consequência, todo contato nefasto do presídio, que é fator dessocializador; b) procurar estimular o senso de responsabilidade do infrator (Regra 1.2); c) almejar a sua ressocialização por vias alternativas, fora da prisão. ${ }^{124}$

Com o advento dessa lei, o rol de Penas Restritivas de Direito (PRD'S) a serem aplicadas aumentou significativamente, possibilitando uma adequação maior à pessoa condenada. As espécies de PRD's, que hoje somam seis, estão previstas no artigo 43 do Código penal, e são elas: I-

\footnotetext{
${ }^{123}$ MINISTÉRIO DA JUSTIÇA/DEPARTAMENTO PENITENCIÁRIO NACIONAL - Modelo de gestão para política prisional. p. 44-45. Disponível em: < http://www.justica.gov.br/modelo-degestao_documento-final.pdf $>$. Acesso em: 15 set. 2018

${ }^{124}$ GOMES, Luiz Flávio. Penas e medidas alternativas à prisão. v. 1. São Paulo: Editora Revista dos Tribunais, 1999. p. 31-32.
} 
prestação pecuniária; II- perda de bens e valores; III- limitação de fim de semana. IV- prestação de serviço à comunidade ou a entidades públicas; Vinterdição temporária de direitos. ${ }^{125}$ Antigamente, só eram espécies de PRD as previstas no inciso IV e V. Foram modificados também os requisitos para o juiz fazer a substituição das Penas Privativas de Liberdade para as PRD'S.

Anteriormente à lei, o juiz não poderia fazer essa conversão no caso do réu ser reincidente. Atualmente, somente os réus reincidentes em crime dolo do mesmo tipo não tem essa possibilidade. Mudaram, também, os patamares no tempo de pena que possibilita a conversão. Antes da alteração, no caso de crime doloso não poderia ser feita a substituição se a condenação fosse igual ou superior a um ano. Se a punição, seja por crime doloso ou culposo, fosse inferior a um ano e superior a seis meses, a prisão se substituiria por PRD. Depois da alteração, a Pena Privativa de Liberdade (PPL) para crimes dolosos não pode ser superior a 4 anos e nem cometida com violência ou grave ameaça. Caso contrário, poderá ser substituída. Tratando-se de crimes culposos, não há mais restrição da quantidade de pena aplicada, mantendo-se apenas o requisito de que não pode ter sigo cometido sob grave ameaça à pessoa. ${ }^{126}$

A lei, no caso das penas de multa substituta, continuou com a possibilidade do magistrado trocar a pena de prisão por uma de multa, nas condenações não superiores a seis meses (art. $60 \$ 2^{\circ}$ do CP). ${ }^{127}$ A novidade

\footnotetext{
125 Art. 43. As penas restritivas de direitos são:

I - prestação pecuniária;

II - perda de bens e valores;

III - limitação de fim de semana.

IV - prestação de serviço à comunidade ou a entidades públicas;

V - interdição temporária de direitos;

VI - limitação de fim de semana.

126 Art. 44. As penas restritivas de direitos são autônomas e substituem as privativas de liberdade, quando:

I - aplicada pena privativa de liberdade não superior a quatro anos e o crime não for cometido com violência ou grave ameaça à pessoa ou, qualquer que seja a pena aplicada, se o crime for culposo;

127 Art. 60 - Na fixação da pena de multa o juiz deve atender, principalmente, à situação econômica do réu.
} 
foi a possibilidade de se trocar a pena de prisão, nas penas inferiores a 1 ano, por uma pena de multa ou por uma pena restritiva de direito (art. 44, $\left.\S 2^{\circ}\right) .{ }^{128}$

Consequência da mudança nas PRDS foi retirar das penitenciárias pessoas que cometeram delitos que não tão graves e que não foram praticados com violência. De acordo com José Flavio Gomes, que defende as Penas e Medidas Alternativas em seu livro "Penas e Medidas Alternativas à Prisão",

No nosso pobre e equivocado modelo penitenciário, que deposita fé no encarceramento de todos os criminosos, a taxa de reincidência é de $85 \%$ e ainda nos damos ao "luxo" de gastar quinhentos reais por mês, por média, com cada um dos cerca de 45 mil pessoas não violentas, cujos delitos causaram prejuízo médio de mais ou menos cem reais. Não fosse por humanitarismo, razoes econômicas já seriam o bastante para uma profunda e radical mudança de atitude e de mentalidade. ${ }^{129}$

$[\ldots]$

Concluiu-se no Relatório Final que todos (Estado, comunidade e infrator) são beneficiados com as penas alternativas. Eis alguns dados relevantes que merecem destaque: no Rio Grande do Sul, o preso comum custa quase trezentos reais por mês; a sanção alternativa custa cerca de cinquenta reais; para cada grupo de três pessoas é preciso um funcionário (no sistema prisional), no alternativo é um para cada cinquenta sancionados; as penas alternativas geram menos reincidência (cerca de $12 \%$ ) que o sistema prisional (em algumas unidades chega a $85 \%$ ); as penas alternativas possibilitam o ressarcimento a sociedade (e também a vítima) dos prejuízos causados pelo delito; facilitam a ressocialização e evitam que o criminoso se torne violento. ${ }^{130}$

Ainda assim, de acordo com os Dados de Mapa de Encarceramento, "constata-se que, entre os apenados, a maioria $(29,2 \%)$ estava cumprindo de quatro a oito anos de prisão, sendo que outros 18,7\% cumpriam, em 2012, pena de até quatro anos de prisão. Ou seja, (...), num sistema superlotado,

$\S 2^{\circ}$ - A pena privativa de liberdade aplicada, não superior a 6 (seis) meses, pode ser substituída pela de multa, observados os critérios dos incisos II e III do art. 44 deste Código.

${ }^{128}$ Art. 44. As penas restritivas de direitos são autônomas e substituem as privativas de liberdade, quando: (Redação dada pela Lei $\mathrm{n}^{\circ} 9.714$, de 1998)

$\S 20$ Na condenação igual ou inferior a um ano, a substituição pode ser feita por multa ou por uma pena restritiva de direitos; se superior a um ano, a pena privativa de liberdade pode ser substituída por uma pena restritiva de direitos e multa ou por duas restritivas de direitos.

${ }^{129}$ GOMES, Luiz Flávio. Penas e medidas alternativas à prisão. v. 1. São Paulo: Editora Revista dos Tribunais, 1999. p. 95.

${ }^{130}$ Ibid. p. 101-102 
18,7\% dos presos não precisariam estar presos, pois estão no perfil para qual o Código de Processo Penal prevê o cumprimento de penas alternativas"131.

Nesse ponto, deve-se atentar para o comprometimento da sociedade com o instituto de Penas e Medidas Alternativas e também da assistência ao Egresso.

Todos estamos convencidos de que nenhuma sanção criminal, seja a de prisão, seja a alternativa, pode ter qualquer prosperidade sem o efetivo apoio da comunidade, que deve compreender o delito não como um fenômeno isolado e resultante de um ser anormal, senão como um acontecimento inerente a convivência social (toda sociedade possui suas taxas de delinquência).

[...]

A comunidade, em suma, deve se aproximar da administração da Justiça Penal (não é pequena aqui a responsabilidade dos próprios juízes em procurar promover essa integração comunitária), mas não só para participar da execução da clássica pena de prisão, senão especialmente das penas e medidas alternativas. não são poucos os dispositivos legais já vigentes que se encaminham nesse sentido. Destacam-se o que a proclamação a criação do Conselho da Comunidade (LEP, artigo 80), com a atribuição de visitar estabelecimentos penais e diligenciar para a obtenção de recursos materiais e humanos para melhor assistência do delinquente (artigo 81), dos patronatos particulares (artigo 78) etc. ${ }^{132}$ ،

\subsection{O direito penal mínimo e a prisão como um mal (ainda) necessário}

Mesmo ainda tendo muito que melhorar e devendo a sociedade lutar pela sua maior aplicabilidade na prática, não se pode deixar de aplaudir as penas e medidas alternativas, que retirando essa parcela social não violenta das penitenciárias já implicam em duas melhorias: a diminuição no hiperencaramento e a diminuição de gastos, que poderão ser realocados para dentro das penitenciários e para as áreas assistências de suporte aos presos que ali dentro continuarão, propiciando condições mais dignas e uma maior possibilidade de reintegração, diminuindo os alarmantes índices de reincidência.

\footnotetext{
${ }^{131}$ MINISTÉRIO DA JUSTIÇA/DEPARTAMENTO PENITENCIÁRIO NACIONAL - Modelo de gestão para política prisional. p. 43. Disponível em: < http://www.justica.gov.br/modelo-degestao_documento-final.pdf> . Acesso em: 15 set. 2018

${ }^{132}$ GOMES, Luiz Flávio. Penas e medidas alternativas à prisão. v. 1. São Paulo: Editora Revista dos Tribunais, 1999. p. 25.
} 
Apesar de se ter absoluta certeza do fracasso da pena privativa de liberdade no que diz respeito à readaptação do condenado à liberdade, e de se reconhecer a importância das Penas e Medidas Alternativas no sentido de prevenir o encarceramento e de se possibilitar uma resposta penal ao condenado sendo feita junto à sociedade, não se pode perder de vista o fato de que, na situação em que se encontra a sociedade brasileira, há um temor em que optar por um abolicionismo radical.

A corrente abolicionista radical, como sabemos, é a luta ardorosamente pela desinstitucionalização total do controle da conduta desviada. Segura do caráter nefasto do sistema penal ("que foi concebido para fazer o mal, que incrementa a violência e que transmite a ideia falsa de que pode ajudar e proteger a vítima"), a corrente abolicionista deposita inteira confiança na resposta de caráter informal, consensual ou "societal". ${ }^{133}$

Isso decorre do fato de que, por mais que muitas vezes o Direito Penal possa ser visto como uma influência demasiada na liberdade de agir das pessoas, muitas vezes também se torna um mecanismo garantidor de direitos daqueles que o Estado tem sob sua proteção. Nesse sentido, o que se pretende defender é que, enquanto não mudar o pensamento social vigente, em que o punitivismo é um discurso constante, com expressões de cunho radical como "bandido bom é bandido morto", é melhor deixar os cidadãos à luz do Direito Penal, do que regidos por uma sociedade que, muitas vezes, poderia ser mais tirânica, ditatorial e sem respeitos às garantias mínimas do ser humano.

Já não parece correto falar em fim do Direito Penal (e de seus instrumentos de coação), senão em fins, aliás, em permanente antinomia ou tensão, porque se de um lado necessitamos da pena (do punitivo, do penal) para a preservação da sociedade, de outro, impossível afastar a imprescindibilidade de critérios de utilidade e garantísticos (do direito) como freios as tendências tirânicas do poder". 134

Conhecem-se todos os inconvenientes da prisão, e sabe-se que é perigosa, quando não inútil. E, entretanto, não "vemos" o que pôr em seu lugar. Ela é detestável solução, de que não se pode abrir mão" 135

\footnotetext{
${ }^{133}$ Ibid. p. 59.

${ }^{134}$ GOMES, Luiz Flávio. Penas e medidas alternativas à prisão. v. 1. São Paulo: Editora Revista dos Tribunais, 1999. p. 24-25

${ }^{135}$ FOUCAULT, Michel. Vigiar e Punir: nascimento da prisão. $42^{\mathrm{a}}$ ed. Rio de Janeiro: Editora Vozes, 2018. p. 224.
} 
Esta constatação leva a uma outra implicação: deve-se, sempre, buscar o mínimo de interferência e a máxima de garantia do direitos. É por isso que, no presente trabalho, decidiu-se por adotar a linha de que devemos seguir um Direito Penal Mínimo. Essa vertente se fundamenta em três afirmativas: i) a falência das prisões e da ideologia do tratamento; ii) o custo elevado do sistema penal, que mesmo caro representa mais efeitos negativos que positivos; e iii) a sua deslegitimação por contar com um atuar discriminatório, selecionando suas vítimas. ${ }^{136}$

Se de um lado não podemos concordar com os postulados da postura políticocriminal neo-retribucionista, até porque hoje ninguém discute que temos uma estonteante "inflação legislativa" no âmbito criminal, o que permite, em tese, que o Estado ingresse excessivamente no âmbito da liberdade do cidadão, e se de outro lado não reivindicamos a ruptura total e absoluta da desistitucionalização das respostas possíveis contra a conduta desviada (o que é sustentado pelo abolicionismo radical), não nos resta outro caminho senão nos inscrevermos entre os adeptos do Direito Penal mínimo(...). ${ }^{137}$

Apesar de se basear no Direito Penal Mínimo, é importante frisar que esse deve ser visto apenas como mecanismo de transição entre um Direito Penal Máximo (ainda presente nas estruturas penais e no anseio social) e um abolicionismo total, que, por ora, não proporcionaria aos privados de liberdade uma garantia incrivelmente maior do que o garantismo penal mínimo poderá lhes fornecer.

Assim, tendo em vista que se deve priorizar, sempre, o desencarceramento, principalmente através da aplicação das Penas e Medidas Alternativas, como já demonstrado, deve-se pensar em alternativas para os cidadãos que, por ainda não ser possível um abolicionismo total, serão captados pela sistema penal e recolhidos às penitenciárias.

A prisão é uma exigência amarga, mas imprescindível. A história da prisão nao é da sua progressiva abolição, mas a de sua reforma. A prisão é concebida modernamente como um mal necessário, sem esquecer que guarda em sua essência contradições insolúveis.

$[\ldots]$

${ }^{136}$ GOMES, Luiz Flávio. Op. Cit., p. 54.

${ }^{137}$ Ibid. p. 54. 
Propõe-se, assim, aperfeiçoar a pena privativa de liberdade, quando necessária, e substituí-la, quando possível e recomendável. ${ }^{138}$

Enfim, reservaram-se as penas privativas de liberdade para os crimes mais graves e para os delinquentes perigoso ou que não se adaptam às outras modalidades de pena. ${ }^{139}$

Passa-se, portanto, nesse ponto, a se analisar uma forma de modificar a realidade penitenciária, visando se construir uma realidade mais próxima ao Direito Penal Mínimo para aqueles que terão, inevitavelmente e por enquanto, se ver adentrando os muros das prisões brasileiras.

${ }^{138}$ BITENCOURT, Cezar Roberto. Falência da pena de Prisão: Causas e Alternativas. $5^{\text {a }}$ ed. São Paulo: Saraiva, 2017. p. 39-40.

${ }^{139}$ Ibid. p. 433. 


\section{Capítulo IV - Outros rumos na Execução Penal: 0 Método APAC}

\subsection{A natureza jurídica da APAC em comparação com as Parcerias Público Privadas (PPP's)}

Optou-se no presente trabalho, antes de se introduzir o método proposto pela APAC, fazer uma análise da sua natureza jurídica. Isso porque atualmente existe uma discussão muito grande a respeito da privatização das prisões no Brasil, assunto polêmico e que parte dos doutrinadores acredita ser eivado de inconstitucionalidade. Dessa forma, pretende-se de forma resumida demonstrar que o método $\underline{\mathbf{N A ̃ O}}$ é uma prisão privada, não sendo inconstitucional e sendo possível, portanto, sua aplicação e utilização como forma alternativa de presídio mais humanitário.

Desde que se começou a falar em prisão privada, pretendendo seus defensores que fosse adotada no Brasil, também começaram a ser ouvidas alusões à APAC, como modelo de prisão privada. Os responsáveis pela APAC e os apaqueanos em geral têm procurado desfazer esse equívoco, esclarecendo a condição jurídica da entidade. ${ }^{140}$

Diversos são os objetivos de internalização do instituto das Parcerias Público Privadas (PPP`s) em nosso ordenamento jurídico pátrio, sendo os mais citados o crescimento econômico através da eficiência de gestão, o aporte de recursos para obras de infra-estrutura e a tão debatida privatização da administração pública, "transferindo para a iniciativa privada grande parte das funções administrativas do Estado"141. Independentemente do eixo, a justificativa é a busca por uma eficiência, que acredita-se ser maior no setor privado. ${ }^{142}$

\footnotetext{
${ }^{140}$ OTTOBONI, Mário. Vamos matar o criminoso? $3^{\text {a }}$ ed. São Paulo: Editora Paulinas, 2001.p. 6970.

${ }^{141}$ DI PIETRO, Maria Sylvia Zanella. Parcerias na Administração Pública: Concessão,

Permissão, Franquia, Terceirização, Parceria Público-Privada e outras formas. $5^{\text {a }}$ ed, São Paulo: Editora Atlas, 2005, p. 159

${ }^{142}$ Ibid. p. 159
} 
O tema sobre sua inconstitucionalidade é complexo e poderia consistir em um trabalho monográfico por si só. Não cabe no momento aprofundar a questão, mas somente alertar que o debate reside no fato de que a Lei das PPP`s, ao tentar introduzir normas que possibilitam a privatização em algumas esferas tendo por base o direito estrangeiro (principalmente o francês e o argentino $)^{143}$, não atentaram para o direito já positivado em nosso ordenamento.

O que se verifica é uma acentuada oposição entre os tecnocratas e os burocratas, entre o princípio da eficiência, pregado pela Ciência da Administração, e o princípio da legalidade imposto pela Constituição e inerente ao Estado de Direito. 144

A igualdade perante a lei, a liberdade de concorrência, a segurança jurídica e o controle efetivo dos gastos públicos - que são, entre outros, pilares básicos do ordenamento jurídico da administração - condicionam ou limitam, em concreto, o alcance o princípio da eficácia. ${ }^{145}$

Em consequência, criou-se um debate a respeito da legalidade dos dispositivos incursos no ordenamento, argumentando em até que ponto a busca pela eficiência poderia influir na legalidade de diversos princípios constitucionais administrativos.

No tema da parceria encontram-se no direito brasileiro inúmeros exemplos de situações que são ou frontalmente ilegais ou, pelo menos, estão em zona fronteiriça com a ilegalidade e a imoralidade administrativa ${ }^{146}$

Não se poderia aplicar no Brasil o instituto pura e simplesmente como havido em legislações alienígenas, sob pena de se resvelar em vitanda inconstitucionalidade. 147

De qualquer forma, antes mesmo da análise dos dispositivos da Lei das PPP's frente a Constituição, alguns argumentam que não é necessário nem chegar a tal minuciosidade, vez que o principal argumento e que por si

\footnotetext{
${ }^{143}$ DI PIETRO, Maria Sylvia Zanella. Parcerias na Administração Pública: Concessão, Permissão, Franquia, Terceirização, Parceria Público-Privada e outras formas. $5^{\text {a }}$ ed, São Paulo: Editora Atlas, 2005, p. 293

${ }^{144}$ Ibid. p. 294

${ }^{145}$ Ibid. p. 296

${ }^{146}$ Ibid. p. 297

${ }^{147}$ CALDAS, Roberto. Parceiras Público-Privadas e suas garantias inovadoras nos contratos administrativos e concessões de serviços públicos. Belo Horizonte: Editora Fórum, 2011, p. 225
} 
só já revelaria a inconstitucionalidade das prisões privadas é o fato de que é o Estado quem detém o monopólio do uso legítimo da força, característica das democracias modernas. Em decorrência, somente ele pode controlar o exercício do direito de punir e manusear os meios coercitivos para destinar a um cidadão uma pena privativa de liberdade como forma de punição por um delito, não podendo transferir para outrém essa função.

A segurança e a justiça são funções próprias do setor público, conforme determina a Constituição do Brasil em seus arts. 2 e 144. Mas, a execução de uma pena restritiva de liberdade é assunto judicial que interessa à segurança da comunidade. Portanto, os estabelecimentos penais, onde se dá tal execução, não podem ser privatizados. ${ }^{148}$

Apesar de interessante a discussão, sua conclusão não altera o objetivo do presente trabalho, vez que o modelo da APAC se difere por sua própria natureza jurídica. Para esclarecermos isso, faz-se necessário uma análise jurídica do instituto das PPP`s para que posteriormente seja desfeita a ideia de que a APAC seja um de seus modelos.

As PPP`s são "um vínculo negocial de trato contínuo entre Administração Pública e os particulares para possibilitar, ao líbito e responsabilidade destes, a atividade de interesse público" ${ }^{149}$. Estão previstas na lei $11.079 / 04$, que em seu artigo $2^{\circ}$, parágrafo $4^{\circ}$, inciso I as define como sendo contratos administrativos cuja duração pode ser de 5 (cinco) a 30 (trinta) anos, podendo ser feito sob duas modalidades: concessão patrocinada ou concessão administrativa. ${ }^{150} \mathrm{Em}$ ambas as modalidades, é importante observar que o objetivo do parceiro privado é alcançar lucro, tendo portanto interesse econômico na atividade.

\footnotetext{
${ }^{148}$ DE CARVALHO, Pedro Armando Egydio. É conveniente privatizar os presídios? Revista Brasileira de Ciências Criminais, ano 2, n. 7, jul-set 1994. p. 114

${ }^{149}$ CALDAS, Roberto. Parceiras Público-Privadas e suas garantias inovadoras nos contratos administrativos e concessões de serviços públicos. Belo Horizonte: Editora Fórum, 2011, p. 186

150 Art. 2o Parceria público-privada é o contrato administrativo de concessão, na modalidade patrocinada ou administrativa.

§ 4ํ É vedada a celebração de contrato de parceria público-privada:

I - cujo período de prestação do serviço seja inferior a 5 (cinco) anos;
} 
A privatização dos presídios é "o exemplo mais corriqueiro de concessão administrativa" ${ }^{151}$ e por esse motivo iremos focar em sua análise, não adentrando na chamada concessão patrocinada. A concessão administrativa envolve somente uma contraprestação pública, não havendo cobrança de tarifa dos usuários, e portanto, a remuneração do particular não se dá pela própria exploração do serviço (visto que não ganha em cima das taxas dos usuários), mas sim por uma remuneração feita direta e exclusivamente pelo Estado.

Suas características são tão singulares que alguns chegam a afirmar que não se trata de concessão, mas de um contrato de prestação de serviços ou até mesmo um contrato de risco de que a Administração Pública seja a usuária direta ou indireta, cumulado ou não com um contrato de concessão de uso de bem público.

Na concessão administrativa, toda a remuneração fica por conta do poder público, porém com a vantagem, para o mesmo, de que ela somente se iniciará após o início, total ou parcial, da prestação do serviço. Além disso, embora o particular tenha que assumir a execução da obra (quando for o caso), por sua própria conta, o poder público terá que prestar pesadas garantias previstas na lei e dividir os riscos do empreendimento com o contratatado nos casos de ocorrência de áleas extraordinárias, o que permite falar em compartilhamento dos riscos e gera certo paradoxo, porque se o poder público não dispõe de recursos para realizar as obras, dificilmente disporá de recursos para garantir o parceiro privado de forma adequada" 152

Assim, as chamadas prisões privadas, constituídas através de contratos administrativos sob modalidade de concessão administrativa de Parceria Público Privada, seguindo todas as fases mencionadas, com processo de licitação e compartilhamento de riscos, manutenção e gerência por conta do parceiro privado, em nada tem em comum com a natureza jurídica da APAC, não podendo de forma alguma ser considerada uma forma de privatização de presídios, pelos motivos a seguir expostos.

\footnotetext{
${ }^{151}$ CALDAS, Roberto. Op. Cit., p. 199-200

${ }^{152}$ DI PIETRO, Maria Sylvia Zanella. Parcerias na Administração Pública: Concessão, Permissão, Franquia, Terceirização, Parceria Público-Privada e outras formas. $5^{\text {a }}$ ed, São Paulo: Editora Atlas, 2005, p. 159
} 
A APAC tem como forma de regime jurídico o modelo das associações civis $^{153}$. De acordo com o artigo 53 do Código Civil ${ }^{154}$, a característica distintiva das associações é que são formadas com fins não econômicos, e geralmente congregam grande número de pessoas perseguindo fins morais, caritativos, literários, artísticos... ${ }^{155}$

Sob esse assunto, Caio Mario da Silva Pereira leciona:

"Caracteriza-se a associação sem fim econômico como a que se não dedica a operações industriais ou comerciais, nem proporciona aos membros uma vantagem pecuniária, tendo o cuidado de assinalar que a procura de vantagens materiais, indispensáveis a que a associação viva e atinja suas finalidades de ordem moral, não retira o caráter não lucrativo do fim social: a contribuição dos associados, a remuneração de certos serviços, a cobrança de ingresso a conferência ou concertos não são característicos do fim lucrativo, como não o é igualmente a verificação de superávit na apuração de balanços periódicos. Não é incompatível com a gratuidade destes a formação de patrimônio, aquisição de sede própria ou de bens de capital". ${ }^{156}$

O Estatuto das APAC prevê a forma em que a APAC obterá receitas e que títulos constituirão suas despesas em seus artigos 62 e 63, respectivamente: ${ }^{157}$

Artigo 62: A receita da APAC será constituída de:

A) contribuições de todo gênero a que são obrigados todos os associados;

B) donativos que não tenham fins determinados;

C) rateios e subscrições destinados às necessidades extraordinárias;

D) convênios e parcerias;

E) subvenções governamentais e,

F) verbas oriundas dos juizados especiais.

\footnotetext{
${ }^{153}$ OTTOBONI, Mário. Vamos matar o criminoso? $3^{\text {a }}$ ed. São Paulo: Editora Paulinas, 2001.p. 21

${ }^{154}$ Art. 53. Constituem-se as associações pela união de pessoas que se organizem para fins não econômicos.

Parágrafo único. Não há, entre os associados, direitos e obrigações recíprocos.

${ }^{155}$ PEREIRA, Caio Mario da Silva. Instituições do Direito Civil. V. 1. Introdução ao Direito Civil.

Teoria Geral do Direito Civil. 26 ${ }^{\text {a }}$ ed. Rio de Janeiro: Editoria Forense, 2013, p.294.

${ }^{156}$ Ibid. p. 295.

${ }^{157}$ OTTOBONI, Mário. Vamos matar o criminoso? $3^{\text {a }}$ ed. São Paulo: Editora Paulinas, 2001.p. 219.
} 
Artigo 63: Constituirão títulos de despesas:
A) o pagamento de impostos, taxas, salários, gratificações e outros;
B) os gastos com atividades discriminadas no artigo $2^{\circ}$ desse Estatuto;
C) os gastos com aquisição e conservação do material de bens na APAC;

D) despesas eventuais devidamente autorizadas;

E) folhas de pagamentos e contribuições fiscais.

Tendo em vista o aludido por Caio Mario, apesar de poder haver uma diferença entre as receitas e despesas, fato é que esse superávit não é revestido em prol dos associados ou sob qualquer forma de distribuição de lucro, o que afasta a natureza econômica da atividade. Esse ponto é a principal diferença entre as Associações Civis e as Parcerias Público Privadas, porque é dele que decorre o distanciamento da forma de criação entre ambas.

Assim, não proporcionando aos membros nenhuma vantagem pecuniária e sendo todo, perseguindo, na maioria das vezes, objetivos morais, sociais, éticos, religiosos, culturais, as associações não podem ser de forma alguma comparada as Parceiras Públicos Privadas (PPP`S).

Portanto, do ponto de vista jurídico civil, é uma entidade da comunidade, com personalidade jurídica, sem fins lucrativos, legalmente declarada de utilidade pública. Do ponto de vista judiciário, é órgão parceiro da justiça, o que subordina ao juiz competente da comarca. Fica, assim, no seu papel de entidade da comunidade, obrigada a prestar, gratuitamente, importante mas sempre acessória colaboração aos órgãos da execução penal. Está claro, portanto, que a APAC não é prisão privada, em nenhum de suas formas, desde a mais extremada, total, até as diversas formas parciais de transferir ou delegar, pelo Estado, a uma empresa privada o exercício do direito de punir na fase de execução penal. ${ }^{158}$

Tendo se demonstrado que a APAC não é uma forma de Parceira Público Privada, nem mesmo na modalidade de concessão administrativa, e

${ }^{158}$ OTTOBONI, Mário. Vamos matar o criminoso? $3^{\text {a }}$ ed. São Paulo: Editora Paulinas, 2001.p. 6970 
portanto não está ligada a nenhum debate a respeito de sua constitucionalidade, sendo sua natureza jurídica de associação civil e tendo, até o presente momento, plena legalidade para atuar, passa-se a analisar suas características gerais e o método apaqueano.

\subsection{Características gerais da APAC}

A Associação de Proteção e Assistência aos Condenados nasceu em São José dos Campos, São Paulo, em 1974. Seu idealizador e líder foi o advogado e jornalista Mario Ottoboni, autor do livro em que o presente trabalho se baseou para entender o método.

Atualmente existem 123 APAC's no Brasil, sendo 49 em funcionamento e 74 em implantação, distribuídas em 11 Estados, sendo a maior quantidade em Minas Gerais (81 no total: 39 em funcionamento e 42 em implantação). ${ }^{159}$ A APAC comporta, ao todo, aproximadamente 2,5 mil recuperandos, dentre os mais de 600 mil presos. ${ }^{160}$

Como órgão parceiro da justiça, a APAC é uma forma de presídio que busca dar assistência aos presos de uma forma mais efetiva que nos presídios comuns, visando a todo o custo o cumprimento integral das normas e dos direitos ao presos previstos na Lei de Execuções Penais.

Apesar de não se deixar de lado o viés retributivo e preventivo da pena, o método valoriza principalmente a ressocialização do condenado, visando sua total reinserção social, diferentemente do que ocorre nos presídios comuns em que a segurança é priorizada ao máximo. Partindo dessa premissa e devido a diferença brutal na importância que é dada a cada um dos tripés dos objetivos da pena, faz-se importante algumas observações

\footnotetext{
${ }^{159}$ FRATERNIDADE BRASILEIRA DE ASSISTÊNCIA AOS CONDENADOS (FBAC) Disponível em </http://www.fbac.org.br/bdfbac/Consulta\%20APACs.php>. Acesso em: 05 out. 2018

${ }^{160}$ FRATERNIDADE BRASILEIRA DE ASSISTÊNCIA AOS CONDENADOS (FBAC) Disponível em http://www.fbac.org.br/index.php/pt/news-3/806-cnj-recomenda-expansao-dasapacs-para-a-reducao-da-reincidencia-criminal-no-pais. Acesso em: 05 out. 2018
} 
gerais que já diferem o método do modelo tradicional de cumprimento de pena.

Antes mesmo de adentrar o estabelecimento da APAC, ainda na fase de seleção, o preso passa a ser chamado de "recuperando". Na opinião dos precursores do método, assim o é porque "apesar de palavras como "preso", "interno", "apenado, "condenado", "reeducando", retratarem a realidade, elas vêm carreadas de um estigma que depreciam o ser humano". ${ }^{161}$ Ainda nessa esteira, o recuperando é obrigado a utilizar um crachá com seu nome, para que seja chamado por ele por todos os membros da APAC, incluindo os membros da diretoria. ${ }^{162}$

O critério de entrada contém requisitos como: i) já ter cumprido pena em um presídio comum pelo menos durante um ano; ii) ter a pena transitada em julgado; iii) necessidade de um requerimento para que seja levado à instituição, com interesse e motivação consignados em um termo específico e iv) habitação familiar na comarca de cumprimento da pena. ${ }^{163}$

Dessa forma, todos os recuperandos, tendo a noção do tratamento que é dado aos presos na ordem penitenciária comum e por livre e espontânea vontade desejaram ir para a APAC. Na visão de muitos, esse é um grande motivo para o sucesso do método.

Ao adentrar a APAC qualquer tipo de contato com armas, grades e agentes penitenciários, que o recuperando tinha antes, cessa de imediato. $\mathrm{O}$ pessoal da guarda que exerce a função de vigilância dos presos não portam nenhum tipo de arma, sendo eles muitas vezes ex recuperandos que estão no regime aberto, no último estágio da sua recuperação, prontos para retornar à convivência social.

\footnotetext{
${ }^{161}$ OTTOBONI, Mário. Vamos matar o criminoso? 3 $3^{\text {a }}$ ed. São Paulo: Editora Paulinas, 2001.p. 46

${ }^{162}$ Ibid. p. 238

${ }^{163}$ INSTITUTO DE PESQUISA ECONÔMICA APLICADA - Reincidência Criminal no Brasil.

Relatório de Pesquisa. p. 68. Disponível em:

<http://www.ipea.gov.br/portal/images/stories/PDFs/relatoriopesquisa/150611_relatorio_reinciden cia_criminal.pdf>. Acesso em: 25 ago. 2018
} 
Um ponto interessante é a proibição de se falar sobre o crime que cometeu e o tempo restante de pena a cumprir. Segundo eles, a partir do momento que você adentra a APAC, todo o seu passado repleto de erros fica para trás, iniciando uma caminhada para sua ressocialização. Além disso, previne algum tipo de segregação ou intriga entre os próprios recuperandos, o que muitas vezes acontece nas penitenciárias comuns por conta da natureza do crime cometido.

\subsection{O histórico do método e suas 12 diretrizes}

A APAC surgiu diante das dificuldades que o trabalho da Pastoral Penitenciária chamada "Amando o Próximo, Amarás a Cristo", que atuava nas penitenciárias dando assistência aos presos, estava tendo para se desenvolver. Era necessário se transformar em uma entidade civil de direito privado, com finalidade definida, para que se obtivesse maior apoio do Poder Judiciário.

A filosofia da Associação de Assistência e Proteção aos Condenados, nome designado quando a pastoral se transformou em um órgão, e que está estampada em todas as suas unidades, é o lema "Matar o criminoso e salvar o homem". Para atingir esse objetivo o método é focado em três principais pilares, sendo eles a valorização humana da pessoa privada de liberdade, a proteção à sociedade (ao se recuperar o infrator) e a assistência à vítima $\mathrm{e}$ seus familiares.

Por ser uma metodologia, pode ser aplicada em qualquer estabelecimento, com a participação da Policia Civil e Militar ou de forma autônoma. O método é utilizado de forma semelhante nos estabelecimentos administrados pela Polícia, mas cuidam somente dos recuperandos em regime aberto e semi-aberto. O órgão que fiscaliza a APAC no cumprimento de suas funções é a Fraternidade Brasileira de Assistência aos Condenados (FBAC). 
Para a APAC poder ser instalada em uma cadeia pública existem alguns requisitos de ordem física-estrutural, uma vez que são necessários para o bom desempenho da proposta: ${ }^{164}$

I) as celas devem ser dotadas de beliches, chuveiros, água e esgoto, sendo recomendável cada cela conter $20 \mathrm{~m}^{2}$, incluindo instalações sanitárias. Essas celas deverão receber no máximo oito recuperandos.

II) duas salas multiuso, sendo a primeira destinada à confecção de trabalhos artesanais e refeitório e a segunda como salão-capela para a realização de cultos, palestras, celebrações, etc.

III) caso o espaço permita, um local para o controle da remição de pena, secretaria e farmácia, podendo ser destinado quando necessário ao atendimento individuais por advogados, juízes, pastores, etc.

IV) quando possível, um gabinete médico-odontológico

Cumpridos esses requisitos e adentrando uma penitenciária, ou sendo construída em modelos autônomos, deverão seguir os 12 elementos fundamentais do método, sem que haja prevalência de um sobre o outro. A seguir, far-se-á uma análise desses elementos. Interessante perceber que esses são apenas reflexos dos três principais pilares da APAC acima expostos.

\subsubsection{A participação da comunidade}

O método apaquiano é conduzido por voluntários, que exercem seu trabalho de forma gratuita e objetivando a ressocialização dos presos. Além disso, a participação da comunidade, mesmo que não trabalhando internamente também é essencial, visto que como associação sem fins lucrativos as parcerias, sob forma de patrocínio ou de sócios contribuidores, são uma grande forma de obtenção de renda. Por esse motivo o método busca

164 OTTOBONI, Mário. Vamos matar o criminoso? $3^{\text {a }}$ ed. São Paulo: Editora Paulinas, 2001.p. 5758 
a todo tempo o engajamento social, principalmente através de campanhas na mídia, audiências públicas, seminários, convite a lideranças, entre outras formas de mobilização.

Tendo a participação voluntária da comunidade, o ambiente se torna muito mais leve e sem rebeliões, vez que é criada uma "atmosfera de laços afetivos, sentimentos de perdão, e, sobretudo, o respeito humano."165

\subsubsection{O recuperando ajudando recuperando}

Prega-se o respeito à vida em comunidade, em que todos se ajudam reciprocamente. Nesse sentido, foram criados dois órgãos internos da APAC: a Representação de Cela e o Conselho de Sinceridade e Solidariedade (CSS).

O primeiro visa manter a disciplina e harmonia entre os recuperando, a limpeza e higiene pessoal da cela, o treinamento de líderes, deixando sempre claro que dentro da APAC não existe o "código de honra" dos presídios comuns, que geram uma pressão dos mais fortes sob os mais fracos. Essa entidade visa, também, promover o incentivo para manter a cela em condições boas.

O segundo órgão é chamado internamente de CSS e auxilia a administração da APAC. Seu presidente é escolhido pela diretoria, que designa os demais membros do conselho. Apesar de não ter poder de decisão, o CSS opina a respeito da disciplina, distribuição de tarefas, necessidade de realização de reformas, promoção de festividades, fiscalização do trabalho para cálculos de remição, etc. É uma forma de se levar à diretoria todos os anseios dos recuperandos, dando uma visão do dia a dia da APAC, buscando sempre soluções benéficas e que tornem o convívio harmônio e saudável.

${ }^{165}$ OTTOBONI, Mário. Vamos matar o criminoso? 3 $3^{\text {a }}$ ed. São Paulo: Editora Paulinas, 2001.p. 66 


\subsubsection{Trabalho}

O trabalho é altamente valorizado no método por ser uma forma do recuperando se identificar com valores de autoconhecimento, de responsabilidade, convivência, melhorando sua auto-imagem e transformando-se como ser humano. Todas as unidades da APAC aplicam o sistema progressivo de pena, utilizando-se do instituto de remição, porque com isso "a liberdade é conquistada por etapas e consenso de responsabilidade."166

Para os presos de regime fechado, o método recomenda trabalhos laborterápicos, como o artesanato. Afirmam, porém, que a interpretação do que seria artesanato deve ser extensiva, não se limitando às "atividades comezinhas" dos presídios comuns. As atividades, portanto, podem ser de tapeçaria, pintura de quadros a óleo, pintura de azulejos, grafite, cerâmica, confecção de redes, toalhas de mesa, cortina, trabalhos em madeira, argila, pintura de faixa, entre outras que permitam principalmente exercitar a criatividade e reflexão.

Mas as atividades do regime fechado não se resumem apenas à essas. Quando possível, deve-se fornecer a possibilidade dos presos atuarem como cabelereiro, auxiliar de enfermagem, garçom, músico, monitor de alfabetização, etc.

O motivo de tantas opções é a preocupação em não fazer com que o trabalho se torne algo mecânico apenas para se conseguir os benefícios de redução de pena através da remição, como acontece nos presídios comuns.

No regime semi-aberto, o recuperando pode sair da APAC para estudar. O objetivo é que todos estejam matriculados em cursos profissionalizantes e, se for o caso, conseguir bolsas de estudos para formar mão-de-obra especializada, como em sapatarias, padarias, oficinas mecânicas, etc.

${ }^{166}$ OTTOBONI, Mário. Vamos matar o criminoso? 3a ed. São Paulo: Editora Paulinas, 2001.p. 49 
No caso do regime aberto, o método exige que o recuperando tenha profissão definida, sendo a proposta de emprego compatível com sua especialidade. Não se pode esquecer que somente chegará a esse regime quando tiver demonstrado mérito e condições psicológicas para retornar ao convívio social, visando proteger a sua família e a sociedade.

\subsubsection{A religião e a importância de se fazer a experiência de Deus}

Deixamos esse tópico para um momento oportuno, em que serão tratadas as questões relativas à religiosidade.

\subsubsection{Assistência jurídica}

Os voluntários da APAC devem estar prontificados a responder as perguntas jurídicas dos recuperandos acerca do seu cumprimento de pena, visto que $95 \%$ da população prisional não reúne condições de contratar um advogado. ${ }^{167}$

Deve-se atentar que o método não se baseia apenas nesse tipo de assistência, sendo necessário se precaver para não transformar uma instituição com esse propósito, como um escritório de advocacia. Os voluntários devem também deixar claro que o cumprimento da pena não se relaciona apenas a questões meramente jurídicas, visto que essas são reflexos de seu mérito e bom comportamento como recuperando.

\subsubsection{Assistência à saúde}

A APAC se preocupa em comportar uma equipe com médicos, enfermeiros, psicólogos, psiquiatras, dentistas, etc. É iniciativa prioritária a APAC conter um gabinete odontológico, uma farmácia e um consultório médico, "evitando assim as escoltas policiais e o desconforto dos

${ }^{167}$ OTTOBONI, Mário. Vamos matar o criminoso? $3^{\mathrm{a}}$ ed. São Paulo: Editora Paulinas, 2001.p. 80 
profissionais voluntários, além de o recuperando ser preservado da humilhação que isso representa." 168

Apesar de contar com soluções para quando a doença já se instaurou, a APAC procura constantemente preveni-las. O objetivo é sempre melhorar as condições de higienização (incluindo a dedetização), pintura, tratamento de água, permitindo banhos regulares de sol, lazer e entretenimento, etc.

\subsubsection{Valorização Humana, base do método APAC}

O método da APAC é todo baseado no ser humano, "em reformular a auto-imagem do homem que errou" ${ }^{169}$. Por esse motivo, na APAC os recuperandos andam com crachás durante todo o dia, sendo chamado pelo nome pelos voluntários, diretoria e outros recuperandos. Outros exemplos são que todos sentam à mesa do refeitório juntos, se alimentando com os mesmos talheres e comendo a mesma comida.

O trabalho de Valorização Humana é focado através de palestras e trabalhos feitos constantemente. Esse trabalho visa fazer o recuperando pensar, e reconhecer os motivos pelo qual está ali, reaprender a importância da família e conhecer seus próprios anseios e projetos de vida.

\subsubsection{A família}

A proximidade do recuperando com a família é pressuposto fundamental para o sucesso do método, "uma vez que os dados estatísticos dão conta de que, entre os fatores determinantes da criminalidade, a família comparece com 98\%." ${ }^{170}$

$\mathrm{O}$ método acredita que dando uma estabilidade à família, quando o recuperando retornar ao seu lar, será muito mais fácil a sua reinserção. Isso porque muitas vezes o ambiente familiar desgastado e em ambientes que

\footnotetext{
${ }^{168}$ Ibid. p. 84

${ }^{169}$ OTTOBONI, Mário. Vamos matar o criminoso? $3^{\text {a }}$ ed. São Paulo: Editora Paulinas, 2001.p. 85

${ }^{170}$ Ibid. p. 86
} 
propiciam o crime levam o homem a delinquir. Reestruturando essa base e a fortalecendo é possível devolver à fonte que o gerou sem preocupação de que o fruto volte a cometer os mesmos erros.

"Na estrutura administrativa, deve ser criado um departamento com o objetivo de cuidar da família, com voluntários treinados por profissionais para que se façam os encaminhamentos e se tomem as providências necessárias. Em muitos casos, e preciso acompanhar a família do recuperando, visitando-a com regularidade e, na medida do possível, encaminhando os filhos à escola, a postos médicos, providenciando cestas básicas etc." ${ }^{171}$

Além disso, é permitido ao recuperando contato telefônico e de correspondência diários com os familiares. A APAC organiza eventos com visitas e atividades especiais nos dias festivos e feriados do ano.

Aspecto importante no contato com a família são as visitas íntimas. $\mathrm{O}$ método da APAC prega que as visitas íntimas sejam semanais e anunciadas por meio de uma escala, o que proporciona uma igualdade de oportunidade a todos os recuperandos. Se possível, deverão ser construídos espaços designados apenas a esses encontros, de preferência perto à saída da APAC, de modo a não expor a/o companheira/o à situações desconfortantes ou constrangimentos.

A existência de um bem-elaborado instrumento regulador de vítimas íntimas familiares é imprescindível para evitar os inconvenientes relacionados a imoralidade, promiscuidade, agenciamento de mulheres e a falta de respeito à equipe de voluntários. ${ }^{172}$

\subsubsection{O voluntário e o curso para sua formação}

Os trabalhos dos voluntários são gratuitos, não sendo fornecido nenhum tipo de contraprestação. A remuneração relacionada aos profissionais que atuam na APAC existe apenas no setor administrativo. $\mathrm{Na}$ visão deles, a partir do momento que você remunera o trabalho do voluntário, você perde a essência do trabalho em conjunto com a comunidade.

\footnotetext{
${ }^{171}$ OTTOBONI, Mário. Vamos matar o criminoso? $3^{\text {a }}$ ed. São Paulo: Editora Paulinas, 2001.p. 87

${ }^{172}$ Ibid. p. 88
} 
Mas não é só isso. Acreditam que quando se trata de prestador de serviços remunerados, "fica mais viável a oferta de propinas, especialmente no ambiente prisional, em que quase tudo tem seu preço." ${ }^{173}$ Essa corrupção, de maneira óbvia, não ajuda na ressocialização e afastamento do crime do recuperando.

Nesse tocante, influencia também o fato de que, muitas vezes quando se trata de trabalho remunerado, o serviço não é feito por amor ou interesse na causa, mas visando somente o benefício econômico. Isso, no método APAC, não se coaduna com os objetivos pretendidos.

Tudo isso é que tem garantido o sucesso da APAC, que tem tornado permanente e vencedora. O respaldo da própria sociedade, evitando que haja dependência de um único órgão que a faça existir, subvencionando-a com exclusividade, emprestalhe eficácia e sentido de durabilidade e serenidade. ${ }^{174}$

Para se tornar um voluntário é necessário a participação no "Curso de Estudos e Formação de Voluntários”, desenvolvido em 42 aulas de uma hora e 30 minutos de duração cada uma, sendo sugerido que sejam ministradas duas aulas por semana. Após um tempo de aprovação, é política da APAC fornecer cursos de aperfeiçoamento dentro dos vários setores que o método dispõe, tais como: relacionamento com as autoridades, com os recuperandos e entre a equipe, espiritualidade, técnicas de comunicação, cursos bíblicos, jurídicos, etc.

\subsubsection{Centro de Reintegração Social (CRS)}

O Centro de Reintegração Social foi criado com objetivo de fornecer ao recuperando um cumprimento de pena no regime aberto próximo ao seu núcleo familiar, "facilitando a formação de mão-de-obra especializada, além de favorecer a reintegração social, respeitando a lei e os direitos do sentenciado." 175

\footnotetext{
${ }^{173}$ Ibid. p. 91

${ }^{174}$ OTTOBONI, Mário. Vamos matar o criminoso? 3ª ed. São Paulo: Editora Paulinas, 2001.p. 92

${ }^{175}$ Ibid. p. 96
} 
O CRS é composto por dois pavilhões, um destinado ao regime semiaberto e outro ao aberto. O principal motivo de sua criação foi a enorme crítica que se faz ao sistema penal comum, que não cumpre com os direitos do preso em regime aberto à serem recolhidos em colônias agrícolas, por não existirem estabelecimentos desse tipo em contingente adequado às nossas proporções (não passam de oito em todo o território nacional).

Em consequência, os tribunais formaram jurisprudência no sentido de que, inviabilizado a possibilidade de se cumprir pena em regime semiaberto, determinar que o preso vá direto ao regime aberto, se beneficiando com o "albergue domiciliar", vez que também não existem Casas de Albergado. $\mathrm{Na}$ visão do método, isso frustra por completo o regime progressivo de pena, e é isso que o CRS visa proteger, para que a progressão e grau de liberdade e independência do preso sejam concedidos de acordo com seus méritos e aptidões.

\subsubsection{Mérito}

O sistema brasileiro de justiça penal se baseia em um sistema progressivo de pena. Por esse motivo, o mérito se sobrepõe ao aspecto temporal do desconto da pena. Na APAC, o mérito é aferido na forma como o recuperando realiza as atividades passadas a ele dia-a-dia, mas não se limitando a um status de obediência, vez que nas prisões comuns essa obediência é alcançada através da coação.

O método, por outro lado, deseja vê-lo prestando serviços, em toda a proposta socializadora, como representante de cela, como membro do CSS, da faxina, na secretaria, no relacionamento com os companheiros, com os visitantes e com os voluntários. Vê-se, pois, que não se trata apenas de uma conduta prisional, mas de um atestado que envolve o mérito do cumpridor da pena. ${ }^{176}$

Tendo em vista a importância do nível de interesse do preso pelos procedimentos adotados no método,

\footnotetext{
${ }^{176}$ OTTOBONI, Mário. Vamos matar o criminoso? 3ª ed. São Paulo: Editora Paulinas, 2001.p. 97
} 
toda tarefa exercida - bem como as advertências, elogios, saídas, etc. - deve integrar sua pasta prontuário. É o registro de seu dia-a-dia na prisão. É ali que se buscarão os elementos necessários para avaliar seu mérito, e não apenas a sua conduta. ${ }^{177}$

Nesse sentido, quando existe a necessidade de se fazer referência a um recuperando em específico, há uma Comissão Técnica de Classificação (CTC), composta por profissionais da APAC e que têm a possibilidade de fazer os exames exigidos para a progressão de regime, como cessão de periculosidade, insanidade mental, etc.

\subsubsection{Jornada de Libertação com Cristo}

Deixamos esse tópico para um momento oportuno, em que serão tratadas as questões relativas à religiosidade.

\subsection{A rotina na APAC}

Como em qualquer sistema progressivo de cumprimento de pena, na APAC os recuperandos que estão em regime fechado tem uma rotina diferente das do semiaberto, que diferem, por sua vez, dos que já beneficiam do último estágio: o regime aberto. Em breve exposição, faremos a análise das atividades incluídas em cada um deles.

Ao condenado em regime fechado existem dois estágios. Assim, todas as atividades fornecidas aos recuperandos que se encontram no estágio inicial também são fornecidas aos recuperandos que estão no primeiro estágio. As atividades do estágio inicial contêm atividades como missa, uso da biblioteca, troca de correspondências com voluntários e palestras. No primeiro estágio, são adicionadas mais atividades, como pesquisa com a família, alfabetização, trabalhos artesanais, integração do CSS, coral ou teatro, esportes, palestras, Alcoólicos Anônimos (AA) e Narcóticos Anônimos (NA), entre outras.

${ }^{177}$ Ibid. p. 97 
Quando o recuperando passa ao regime semiaberto é feita uma solenidade em que comparecem os voluntários, padrinhos e familiares do recuperando. Nela, se "assume o compromisso de acatar respeitosamente as normas disciplinares da entidade e assina o termo perante a comunidade" 178 . A partir dessa celebração, o recuperando passará a atividades como saídas para procurar trabalho, participação em cursos profissionalizantes, intensificação no processo de reintegração recuperando-família-sociedade, entre outras. Não se deve esquecer que as atividades são somadas as que o recuperando já exercia.

Chegando, finalmente, ao regime aberto, última etapa de sua jornada, são somadas à necessidade de indenização da vítima, da identificação com a escala de recuperação da APAC, trabalho profissional e frequência a Cursos de Formatação e Valorização Humana.

Apesar de todos esses direitos elencados, os recuperandos também contam com um rol de obrigações a seguirem, apesar de muito mais restritos. O artigo 38 do Regulamento ${ }^{179}$ prevê os deveres do recuperando, independentemente do estágio ou regime em que se encontra. São elas:

1- Não infringir as normas estabelecidas no Provimento, no Regulamento da Cadeia e no Regimento Interno do Centro de Reintegração Social da APAC;

2- Não ingerir qualquer espécie de bebida alcoólica ou substâncias tóxicas;

3- Não frequentar casas de jogo, de prostituição ou de reputação duvidosa

4- Não fazer brincadeiras de mau gosto ou entrar em luta corporal com qualquer pessoa;

\footnotetext{
${ }^{178}$ OTTOBONI, Mário. Vamos matar o criminoso? $3^{\text {a }}$ ed. São Paulo: Editora Paulinas, 2001.p. 124

179 OTTOBONI, Mário. Vamos matar o criminoso? $3^{\mathrm{a}}$ ed. São Paulo: Editora Paulinas, 2001.p. 235
} 
5- Não ausentar-se do estabelecimento a que seja destinado, salvo na forma e ocasiões expressamente autorizadas;

6- Não portar armas;

Como em qualquer sistema progressivo de regime, o descumprimento desses deveres pode acarretar, de acordo com a gravidade do ato cometido, a regressão de regime ou mesmo a proibição de progressão, sem prejuízo de qualquer outra penalidade prevista anteriormente e de instauração de ação penal ou inquérito. Quando a pena implicar o rebaixamento de regime não é a APAC que a determina, e sim a autoridade judicial, que pode ser provocada pela instituição, se dando sempre oitiva ao Ministério Público.

\subsection{O método em números}

É interessante nesse momento fazermos uma análise numérica do sistema da APAC. Apesar de não termos estudos nos mesmos níveis de precisão dos realizados no sistema penitenciário comum, expostos no segundo capítulo do presente trabalho, é possível perceber com os que estão ao nosso alcance como a diferença do método produz resultados significativos.

Uma primeira comparação importante a se fazer é a questão do custo do preso em um sistema penitenciário comum em comparação ao preso de uma APAC. Segundo a Secretaria de Estado de Justiça e Direitos Humanos (SEJUDH), os valores gastos com cada detento no sistema comum podem variar entre R \$ 1,9 mil e $\mathrm{R} \$ 5$ mil ao mês. ${ }^{180} \mathrm{Na}$ APAC, o preso custa menos da metade disso. Em Minas, por exemplo, o custo mensal de um reeducando na APAC é de $\mathrm{R} \$ 1$ mil, enquanto no regime comum o custo é de $\mathrm{R} \$ 2$ mil.

\footnotetext{
${ }^{180}$ HOLLAND, Carolina. Gasto com preso chega a ser 10 vezes maior que custo por aluno em MT. Disponível em 〈http://g1.globo.com/mato-grosso/noticia/2017/01/gasto-com-preso-chega-ser-10-vezes-maiorque-custo-por-aluno-em-mt.html)>. Acesso em: 20 set. 2018
} 
A abertura de uma vaga no regime alternativo custa $\mathrm{R} \$ 27$ mil, e no convencional, R\$ 37 mil. ${ }^{181}$

Segundo os cálculos do gerente de metodologia da entidade, Roberto Donizetti, menos da metade do valor mensal que o Estado destina a manter uma pessoa sob custódia no sistema prisional tradicional. Em Minas Gerais, por exemplo, o preso custa em média $\mathrm{R} \$ 2,7$ mil por mês pelo sistema tradicional dos presídios do Estado e R\$ 1 mil pelo método de ressocialização da FBCA. ${ }^{182}$

$\mathrm{Na}$ época da reportagem acima, do Conselho Nacional de Justiça, existiam 39 unidades APAC's mineiras, onde cumpriam pena cerca de 3 mil homens e mulheres. O custo deles era em torno de $\mathrm{R} \$ 3$ milhões de reais por mês. Caso estivessem em uma prisão do sistema comum, custariam 4 vezes mais, o que soma uma diferença de $\mathrm{R} \$ 108$ milhões por ano.

Sob esse ponto, alguns podem erroneamente pensar que o método é menos custoso porquê de alguma forma deixa de fornecer alguma atividade ou subsídio ao preso. Impressão equivocada, vez que, além de tudo o que foi exposto a respeito da ideologia do método, o Relatório de Reincidência Criminal ao visitar algumas unidades de APAC afirmou que TODOS os recuperandos estavam inseridos em uma das atividades de trabalho ou estudo.

Havia duas salas de aula, e com a parceria do Serviço Social da Industria de São Paulo (Sesi)/Serviço Nacional de Aprendizagem Comercial (Senac), eram oferecidos cursos por meio de metodologia de teleaula, integrando o EJA. ${ }^{183}$

Interessante analisar que o fato de se disponibilizar trabalhos e estudos a todos não só não aumenta no custo do preso, como o diminui. Esse ponto

\footnotetext{
${ }^{181}$ ESTADÃO CONTEÚDO - Disponível em: < https://www.hojeemdia.com.br/primeiroplano/preso-da-apac-fica-menos-tempo-na-pris\%C3\%A3o-o-que-reflete-no-custo-diz-juiz-dotjmg-1.438846> . Acesso em: 20 set. 2018

182 CONSELHO NACIONAL DE JUSTIÇA - Ressocializar presos é mais barato do que mantêlos em presídios. Disponível em: <http://www.cnj.jus.br/noticias/cnj/84606-apac-onderessocializar-preso-custa-menos-do-que-nos-presidios> Acesso em: 20 set. 2018 ${ }^{183}$ INSTITUTO DE PESQUISA ECONÔMICA APLICADA - Reincidência Criminal no Brasil. Relatório de Pesquisa. p. 69. Disponível em: $<$ http://www.ipea.gov.br/portal/images/stories/PDFs/relatoriopesquisa/150611_relatorio_reinciden cia_criminal.pdf $>$. Acesso em: 25 ago. 2018
} 
bem é observado pelo juiz auxiliar da presidência do Tribunal de Justiça de Minas Gerais, Thiago Colnago Cabral, na seguinte passagem:

Como o preso trabalha, estuda e frequenta biblioteca, a cada 100 dias cumpridos da pena, ele ganha outros 56, ou seja, é como se tivesse cumprido 146. No sistema convencional, isso é praticamente impossível, ou seja, o preso da APAC fica menos tempo na prisão, o que também reflete no custo. ${ }^{184}$

Além disso, os dados colhidos pelo Relatório de Reincidência Criminal nas mesmas visitas afirmam que nas APAC`s cada cela abrigava quatro recuperandos, havendo pavilhões diferenciados aos presos de regime fechado e semiaberto.

Não existia superpopulação carcerária: eram 94 presos do regime fechado e 33 do semiaberto. Não havia divisão por tipo penal. Também existiam jardins e espaços destinados a refeições, lazer, laborterapia, atividade religiosas, atendimento psicossocial e palestras, principalmente às atividades de valorização humana. ${ }^{185}$

Também de forma equivocada alguns críticos poderão conferir ao sucesso do método o fato de existir um "processo seletivo" para o preso adentrar a APAC, escolhendo presos "com mais chances de ressocialização", o que justificaria a diferença absurda nos níveis de reincidência. Não é isso o que ocorre na prática.

Em análise feita dos presos integrantes do método, chegou-se à conclusão que $75 \%$ dos presos são analfabetos ou semianalfabeto; 97\% a $98 \%$ dos presos são provenientes de famílias desestruturadas; $86,6 \%$ são usuários de drogas (cocaína, maconha, crack, álcool e outras); 43\% são negros; $95 \%$ são pobres, dos quais $85 \%$ não podem constituir um advogado particular. Mais de $90 \%$ apresentam doenças, como moléstias de pele, aids, tuberculose ou simples dores de cabeça. $68 \%$ são jovens e apenas $1 \%$ exerceu

\footnotetext{
${ }^{184}$ ESTADÃO CONTEÚDO - Preso na APAC fica menos tempo na prisão, o que reflete no custo, diz juiz do TJMG. Disponível em: <https://www.hojeemdia.com.br/primeiro-plano/preso-da-apacfica-menos-tempo-na-pris\%C3\%A3o-o-que-reflete-no-custo-diz-juiz-do-tjmg-1.438846)> ${ }^{185}$ INSTITUTO DE PESQUISA ECONÔMICA APLICADA - Reincidência Criminal no Brasil. Relatório de Pesquisa. p. 67. Disponível em: $<\mathrm{http} / / /$ www.ipea.gov.br/portal/images/stories/PDFs/relatoriopesquisa/150611_relatorio_reinciden cia_criminal.pdf $>$. Acesso em: 25 ago. 2018
} 
uma ocupação produtiva, ainda que muitos tenham experiência de trabalho. ${ }^{186}$

Ainda assim, em geral, a reincidência nas APAC's é de 15\%, chegando algumas unidades à obter Índice de reincidência inferior a 5\%, estatística confirmada pela Prision Fellowship Internacional (PFI) ${ }^{187}$, enquanto no sistema comum o índice de reincidência geral chega à $80 \%$, como já retratado anteriormente. "Em se tratando do quesito segurança, apesar de não existirem agentes penitenciários e ser proibido o uso de armas, desde 1972 nunca houve registro de motins ou rebeliões. O porcentual de fuga é de $1 \%$ da população carcerária." 188

Os números não existem em abrangência e não são tão específicos, mas já servem ao propósito. É possível perceber que ao seguir a LEP e propiciar aos recuperandos todos os direitos previstos em lei, somado à uma atenção diferenciada por parte dos voluntários, que cumprem os 12 elemento do método de forma respeitosa, a APAC se cristaliza como um método eficaz e de baixo custo. Como consequência, diminui o nível de reincidência, o que a longo prazo reduz a população carcerária.

De outro lado, o sistema comum, não sabendo lidar com uma população carcerária que só aumenta e tende a crescer, muito por conta das leis cada vez mais punitivistas e que visam, baseados em um impacto público e social, um maior encarceramento, acaba por não cumprir a Lei de Execuções Penais.

Essa omissão na assistência que deve pregar diminui sua eficácia e contribui para o aumento dos níveis de reincidência, o que, por derradeiro, mantém o custo do sistema elevado, visto que a "porta de entrada" se torna

\footnotetext{
${ }^{186}$ OTTOBONI, Mário. Vamos matar o criminoso? $3^{\text {a }}$ ed. São Paulo: Editora Paulinas, 2001.p. 146

${ }^{187}$ Ibid. p. 105

${ }^{188}$ ESTADÃO CONTEÚDO - Preso na APAC fica menos tempo na prisão, o que reflete no custo, diz juiz do TJMG. Disponível em: <https://www.hojeemdia.com.br/primeiro-plano/preso-da-apacfica-menos-tempo-na-pris\%C3\%A3o-o-que-reflete-no-custo-diz-juiz-do-tjmg-1.438846. Acesso em: 20 set. 2018
} 
cada vez mais larga, com novos criminosos capturados pela legislação encarceradora e os antigos que retornam. Sem sobra de orçamento, não se consegue investir no sistema, o que gera um ciclo vicioso de problemas sem vistas à uma solução.

Luiz Carlos Rezende e Santos, juiz auxiliar da Presidência do Conselho Nacional de Justiça (CNJ) e integrante do Departamento de Monitoramento e Fiscalização do Sistema Carcerário e do Sistema de Execução de Medidas Socioeducativas, expôs sua opinião:

Acreditamos que o sistema prisional pode melhorar muito e que a APAC pode contribuir com essa melhora. O método é desenvolvido há mais de quarenta anos e nunca houve um caso de grave violência no interior de suas unidades, nunca houve um homicídio e jamais ocorreu motim ou rebelião. A reincidência chega a ser 10 vezes inferior à convencional, e a manutenção dos centros de reintegração social é, em média, três vezes inferior ao custo do sistema comum. ${ }^{189}$

Apesar de todos os elogios e os resultados positivos, como em qualquer método existem críticas e pontos a serem modificados ou ao menos repensados. Assim, passa-se a expor criticamente, mas também como forma de análise, os dois tópicos restantes dentro dos 12 elementos do método da APAC, e que abordam a questão da religiosidade.

\subsection{Ponto que merece questionamento}

\subsubsection{A religiosidade vista como fator obrigatório para o sucesso do método}

A religiosidade é um discurso marcante nos propagadores do método e na forma como ele é aplicado. Pode se afirmar, inclusive, que muitas pessoas têm algum receio em relação ao método devido à sua fama de ser uma instituição evangélica, não se interessando por conhecer melhor acreditando ser uma forma de assistencialismo por parte da Igreja.

\footnotetext{
${ }^{189}$ CONSELHO NACIONAL DE JUSTIÇA - CNJ recomenda a expansão das APAC's para a redução da reincidência criminal no país. Disponível em: <http://www.cnj.jus.br/noticias/cnj/61552-cnj-recomenda-expansao-das-apacs-para-a-reducao-dareincidencia-criminal-no-pais $>$. Acesso em: 20 set. 2018
} 
Há críticas severas de inúmeros religiosos e penitenciaristas a propósito do método apaqueano, o qual, se não viola a liberdade de crença do recluso, ao menos o induz a conformar-se exteriormente, sem convicção pessoal, às rígidas normas de conduta, para daí tirar algum inconfessado proveito. ${ }^{190}$

Durante toda a exposição do método pelo seu precursor Mario Ottoboni a religiosidade é relembrada constantemente em diversos trechos. Dois de seus elementos, que não foram analisados na seção pertinente, dizem respeito à religião. São eles: "A religião e a importância de se fazer a experiência de Deus" e a "Jornada de Libertação com Cristo".

O primeiro existe como forma de incentivo aos recuperandos a terem uma religião. De acordo com o método, a religião não basta para que o preso se ressocialize, mas é fator primordial. A APAC, por conta disso, produz um intenso trabalho religioso, com orações diárias, palestras sobre o tema e encontros semanais de evangelização.

O método Apac proclama, pois, a necessidade imperiosa de o recuperando ter uma religião, crer em Deus, amar e ser amado, não impondo este ou aquele credo, e muito menos sufocando ou asfixiando o recuperando com chamamentos que o angustiam, em vez de fazê-lo refletir. ${ }^{191}$

Apesar de se declararem abertos a outras religiões, até 1985, 98\% dessa população era constituída por cristãos. Em 2006 esse quadro apresentava uma outra face, com $20 \%$ dos presos declarando-se de outros credos.

A maior parte é evangélica. A Apac é entidade basicamente católica e não faz. O método prega que você tem que ter uma religião independente de qual for" (preso da APAC no regime fechado). ${ }^{192}$

O segundo elemento religioso, a "Jornada de Libertação com Cristo", é considerado o "ponto alto da metodologia." 193 A jornada consiste em 3 dias

\footnotetext{
${ }^{190}$ DE CARVALHO, Pedro Armando Egydio. É conveniente privatizar os presídios? Revista Brasileira de Ciências Criminais, ano 2, n. 7, jul-set 1994. p. 114

${ }^{191}$ OTTOBONI, Mário. Vamos matar o criminoso? $3^{\text {a }}$ ed. São Paulo: Editora Paulinas, 2001.p. 80

${ }^{192}$ INSTITUTO DE PESQUISA ECONÔMICA APLICADA - Reincidência Criminal no Brasil.

Relatório de Pesquisa. p. 70. Disponível em:

$<\mathrm{http} / / /$ www.ipea.gov.br/portal/images/stories/PDFs/relatoriopesquisa/150611_relatorio_reinciden cia_criminal.pdf $>$. Acesso em: 25 ago. 2018

${ }^{193}$ OTTOBONI, Mário. Op. Cit., p. 98.
} 
de reflexão com os recuperandos, consistentes em palestras, testemunhos, músicas, mensagens, ministrados por membros do voluntariado, o que permite que se passe os conceitos de forma mais "coloquial".

A jornada se divide em duas etapas: a primeira preocupa-se em revelar Jesus Cristo aos jornadeiros. Sua bondade, autoridade, misericórdia, humildade, senso de justiça e igualdade. Para Deus todos são iguais e titulares dos mesmos direitos. A parábola do filho pródigo é o fio condutos da Jornada, culminando com o retorno ao seio da família, num encontro emocionante do jornadeiro com seus parentes. A segunda etapa ajuda o recuperando a rever o filme da própria vida, para conhecerse melhor. A jornada de Libertação promove, nessa etapa, o encontro do recuperando consigo mesmo, com Deus e com o semelhante, para voltar aos braços do Pai com o coração pleno de amor. ${ }^{194}$

Como se percebe, a metodologia gira toda em torno de uma visão de que o recuperando, quando em contato com Deus e Cristo, facilita a sua recuperação. Acreditamos que a religiosidade para muitas pessoas realmente serve como subterfúgio e o início de uma nova vida. Não há dúvidas de que para alguns é realmente a sua salvação.

Porém, como estamos propondo no presente trabalho uma forma alternativa de execução penal frente ao sistema penitenciário comum, não podemos aceitar, sem fazer críticas, a obrigatoriedade do recuperando ter alguma crença (independente de qual seja) para que seja considerado "recuperável". Dois motivos concorrem para a posição adotada.

O primeiro deles é o fato do Brasil ser um Estado Laico, o que significa que deve ter "postura neutra no campo religioso", tendo como princípios "a imparcialidade em assuntos religiosos, não apoiando ou discriminando nenhuma religião"195. Dessa forma, obrigar um recuperando que contém todos os requisitos objetivos para adentrar ao método a ter uma religião não nos parece uma imparcialidade e liberdade religiosa.

Além disso, o segundo motivo, muito relacionado com o acima exposto, é a ideia de que mesmo com todos os outros elementos do método,

\footnotetext{
${ }^{194}$ OTTOBONI, Mário. Vamos matar o criminoso? $3^{\text {a }}$ ed. São Paulo: Editora Paulinas, 2001.p. 99

${ }^{195}$ Significado de Estado Laico - Disponível em: <(https://www.significados.com.br/estadolaico/> . Acesso em: 15 de out. 2018
} 
uma pessoa que não comunga de crença alguma torna mais difícil a sua recuperação. Essa limitação, também pode ser vista como uma discriminação, visto que "criminosos sem fé" também são recuperáveis. Desse pensamento a APAC em tese também compartilha, visto que seu lema afirma: "Ninguém é irrecuperável" Ninguém mesmo, inclusive os que não tem crença religiosa.

Dessa forma, apesar de concordamos que é necessário fornecer a possibilidade de prática religiosa dentro das prisões em suas diversas formas de expressão, visto que muitas vezes os presos se identificam com a prática, acreditamos que esse contato não deve ser de forma alguma obrigatório, ou seja, não deve fazer parte das "atividades diárias" do preso do sistema comum ou do recuperando, podendo ser, no máximo, uma alternativa das atividades na hora de lazer, deixando a critério do preso a sua escolha ou não. 


\section{CONCLUSÃO}

Por todo o exposto, tendo certeza que o sistema penal é um mecanismo discriminatório feito para a manutenção de um status quo da classe dominante sob um grupo determinado de pessoas, infringindo-as penas de prisão que não tem como objetivo ressocializá-lo para a volta do convívio social, mas sim o contrário, visto que todo o sistema interno da penitenciária, somado à falta de recursos que gera diminuta assistência material, saúde, social, etc., se torna uma forma de "escola da criminalidade", com vivências diárias equiparadas a tortura, propõe-se uma forma alternativa de execução penal, mais voltada para a retomada do ser humano que errou à sociedade, visando protegê-la.

Como em nosso país o cenário em que nos encontramos torna difícil, se não impossível, se falar em um abolicionismo total, optamos por nos concentrar no Direito Penal como uma forma de se defender os direitos e garantias mínimos aos condenados frente a uma sociedade punitivista. Através das penas e medidas restritivas é possível se desafogar as penitenciárias de "criminosos menos violentos", reduzindo seu hiperencarceramento. Mas não basta isso. Deve-se reestruturar todo o aparato interno das penitenciárias que continuam a recolher presos todos os dias, e que, infelizmente, não tem conseguido fornecer a assistência mínima que a Lei de Execução Penal prevê como um direito.

A APAC se difere dos mecanismos que usualmente se propõe como alternativa ao fracasso do sistema comum, visto que essa normalmente é ligada às privatizações das prisões brasileiras. A associação, como demonstrado, não é uma prisão privada sob qualquer forma de Parceria Público-Privada. Sob forma de Associação Civil sem fins lucrativos, tendo como base estímulos governamentais, a receita de seus associados e parceiras 
externas com entes não governamentais, é eivada de constitucionalidade e, portanto, tem permissão jurídica para atuar.

O método, como demonstrado, conta com 12 elementos que em conjunto propiciam um melhor cumprimento de pena, fornecendo ao recuperando desde assistências básicas como alimentação e saúde, até cursos profissionalizantes, mantendo durante todo o período contato familiar diário e visitas semanais, além de possibilidade de assistência jurídica disposta a sanar quaisquer dúvidas que surjam.

Sendo chamado pelo nome, não convivendo com armas ou qualquer forma de violência, tendo suas atitudes observadas e celebradas com uma minuciosa análise de mérito que o permite usufruir dos benefícios legais, o recuperando adentra uma realidade da qual não fazia parte. Com voluntários e diretores que desejam sua recuperação, com sua família preparada para recebê-lo de volta e com a possibilidade de conseguir um emprego, a chance de retornar ao mundo da criminalidade se reduz significativamente, fato comprovado pelo baixo índice de reincidência comparado ao sistema penitenciário comum.

Como qualquer sistema, há críticas e, portanto, melhorias que podem ser feitas. De qualquer forma, interessante analisar o sucesso do método, apesar de ainda restrito à alguns Estados do país, buscando acentuar as diferenças desse para o sistema penitenciário comum, como forma de tentar levar o método cada vez mais para dentro das prisões brasileiras ou, de alguma forma, que esse seja aplicado autonomamente com a criação de espaços destinados à esse fim.

Somente com a renovação e com o estímulo a novas ideias e metodologias que é possível transformar o modelo atual evidentemente falido, ou ao menos melhorar o sistema de execução penal brasileiro, visando uma execução mais humanitária e menos discriminatória que tem como objetivo maior a ressocialização do seu condenado para que volte à sociedade 
tendo noção de seu papel de cidadão, cumprindo os seus deveres, respeitando as leis e usufruindo de sua liberdade. 


\section{BIBLIOGRAFIA}

\section{Livros:}

ARENDT, Hannah. Antissemitismo. In: Origens do Totalitarismo: antissemitismo, imperialismo e totalitarismo. Companhia das Letras, $3^{\mathrm{a}}$ ed., 2013, p. 17-111.

, Hannah.. Imperialismo. In: Origens do Totalitarismo: antissemitismo, imperialismo e totalitarismo. Companhia das Letras, $3^{\mathrm{a}}$ ed., 2013, p. 147-300.

BECCARIA, Cesare. Dos delitos e das penas. $2^{\mathrm{a}}$ ed. São Paulo: Edipro, 2015, $127 \mathrm{p}$.

BITENCOURT, Cezar Roberto. Falência da pena de Prisão: Causas e Alternativas. $5^{\mathrm{a}}$ ed. São Paulo: Saraiva, 2017, 453 p.

CALDAS, Roberto. Parceiras Público-Privadas e suas garantias inovadoras nos contratos administrativos e concessões de serviços públicos. Belo Horizonte: Editora Fórum, 2011, 312 p.

DI PIETRO, Maria Sylvia Zanella. Parcerias na Administração Pública: Concessão, Permissão, Franquia, Terceirização, Parceria Público-Privada e outras formas. $5^{\mathrm{a}}$ ed, São Paulo: Editora Atlas, 2005, 449 p.

FOUCAULT, Michel. Vigiar e Punir: nascimento da prisão. 42a ed. Rio de Janeiro: Editora Vozes, 2018, 302 p. 
GOMES, Luiz Flávio. Penas e medidas alternativas à prisão. v. 1. São Paulo: Editora Revista dos Tribunais, 1999, 185 p.

OTTOBONI, Mário. Vamos matar o criminoso? $3^{\mathrm{a}}$ ed. São Paulo: Editora Paulinas, 2001, 329 p.

PEREIRA, Caio Mario da Silva. Instituições do Direito Civil. V. 1. Introdução ao Direito Civil. Teoria Geral do Direito Civil. 26 ${ }^{\mathrm{a}}$ ed. Rio de Janeiro: Editoria Forense, 2013, 597 p.

TAVARES, Luisa de Araujo. Efeitos de Prisionização: A ineficácia da prisão como sanção penal. $1^{\text {a }}$ ed. Rio de Janeiro: Editora Palma, 2018, 83 p.

THOMPSON, Augusto. A questão penitenciária. $5^{\mathrm{a}}$ ed. Rio de Janeiro: Editora Forense, 2002. 145 p.

Augusto. Quem são os criminosos. $2^{\mathrm{a}}$ ed. Rio de Janeiro: Editora Lumen Juris, 2007. 173 p.

\section{Artigos:}

DE CARVALHO, Pedro Armando Egydio. É conveniente privatizar os presídios? Revista Brasileira de Ciências Criminais, Brasil, p. 114, ano 2, n. 7, jul-set 1994. 


\section{Sites:}

BOTTARI, Elenilce. No Rio, apenas $4 \%$ dos presos cumprem lei que estabelece que detentos trabalhem. Jornal O Globo, 08/08/2018 - 04:30. Disponível em: <https://oglobo.globo.com/rio/no-rio-apenas-4-dos-presoscumprem-lei-que-estabelece-que-detentos-trabalhem22958747\#ixzz5Nb086BMx stest>. Acesso em: 2 out. 2018. COMO MATAR UM CRIMINOSO - Apac: o método na prática. Disponível em: < http://comomatarumcriminoso.com.br> . Acesso em: 17 out. 2018

CONSELHO NACIONAL DE JUSTIÇA - CNJ recomenda a expansão das APAC's para a redução da reincidência criminal no país. Disponível em: <http://www.cnj.jus.br/noticias/cnj/61552-cnj-recomenda-expansao-dasapacs-para-a-reducao-da-reincidencia-criminal-no-pais> . Acesso em: 20 set. 2018

CONSELHO NACIONAL DE JUSTIÇA - Ressocializar presos é mais barato do que mantê-los em presídios. Disponível em: <http://www.cnj.jus.br/noticias/cnj/84606-apac-onde-ressocializar-presocusta-menos-do-que-nos-presidios> Acesso em: 20 set. 2018

ESTADÃO CONTEÚDO - $\quad$ Disponível em: <https://www.hojeemdia.com.br/primeiro-plano/preso-da-apac-fica-menostempo-na-pris\%C3\%A3o-o-que-reflete-no-custo-diz-juiz-do-tjmg1.438846> Acesso em: 20 set. 2018

ESTADÃO CONTEÚDO - Preso na APAC fica menos tempo na prisão, o que reflete no custo, diz juiz do TJMG. Disponível em: <https://www.hojeemdia.com.br/primeiro-plano/preso-da-apac-fica-menos- 
tempo-na-pris\%C3\%A3o-o-que-reflete-no-custo-diz-juiz-do-tjmg1.438846. Acesso em: 20 set. 2018

FRATERNIDADE BRASILEIRA DE ASSISTÊNCIA AOS $\begin{array}{lllll}\text { CONDENADOS } & \text { (FBAC) } & - & \text { Disponível }\end{array}$ $</$ http://www.fbac.org.br/bdfbac/Consulta\%20APACs.php>. Acesso em: 05 out. 2018

FRATERNIDADE BRASILEIRA DE ASSISTÊNCIA AOS $\begin{array}{lllll}\text { CONDENADOS } & \text { (FBAC) } & - & \text { Disponível }\end{array}$ http://www.fbac.org.br/index.php/pt/news-3/806-cnj-recomenda-expansaodas-apacs-para-a-reducao-da-reincidencia-criminal-no-pais. Acesso em: 05 out. 2018

HOLLAND, Carolina. Gasto com preso chega a ser 10 vezes maior que custo por aluno em MT. Disponível em <http://g1.globo.com/matogrosso/noticia/2017/01/gasto-com-preso-chega-ser-10-vezes-maior-quecusto-por-aluno-em-mt.html)>. Acesso em: 20 set. 2018

IMPARCIALIDADE OU CEGUEIRA: Um estudo sobre prisões provisórias e alternativas penais. Instituto de Estudos da Religião (ISER). Disponível em: $<$ https://www.youtube.com/watch?v=a7G5tSH6COQ $>$. 6min38-6min58. Acesso em: 18 set. 2018.

INSTITUTO DE PESQUISA ECONÔMICA APLICADA - Reincidência Criminal no Brasil. Relatório de Pesquisa. p. 24. Disponível em: $<$ http://www.ipea.gov.br/portal/images/stories/PDFs/relatoriopesquisa/1506 11_relatorio_reincidencia_criminal.pdf $>$. Acesso em: 25 ago. 2018. 
MINISTÉRIO DA JUSTIÇA E SEGURANÇA PÚBLICA/Departamento Penitenciário Nacional- Levantamento Nacional de Informações Penitenciárias (INFOPEN). p. 46. Disponível em: <http://depen.gov.br/DEPEN/depen/sisdepen/infopen/relatorio_2016_2211.pdf>. Acesso em: 14 out. 2018.

\section{MINISTÉRIO DA JUSTIÇA/DEPARTAMENTO PENITENCIÁRIO} NACIONAL - Modelo de gestão para política prisional. p. 25. Disponível em: < http://www.justica.gov.br/modelo-de-gestao_documento-final.pdf> . Acesso em: 15 set. 2018.

Significado de Estado Laico - Disponível em: <(https://www.significados.com.br/estado-laico/> . Acesso em: 15 out. 2018 